
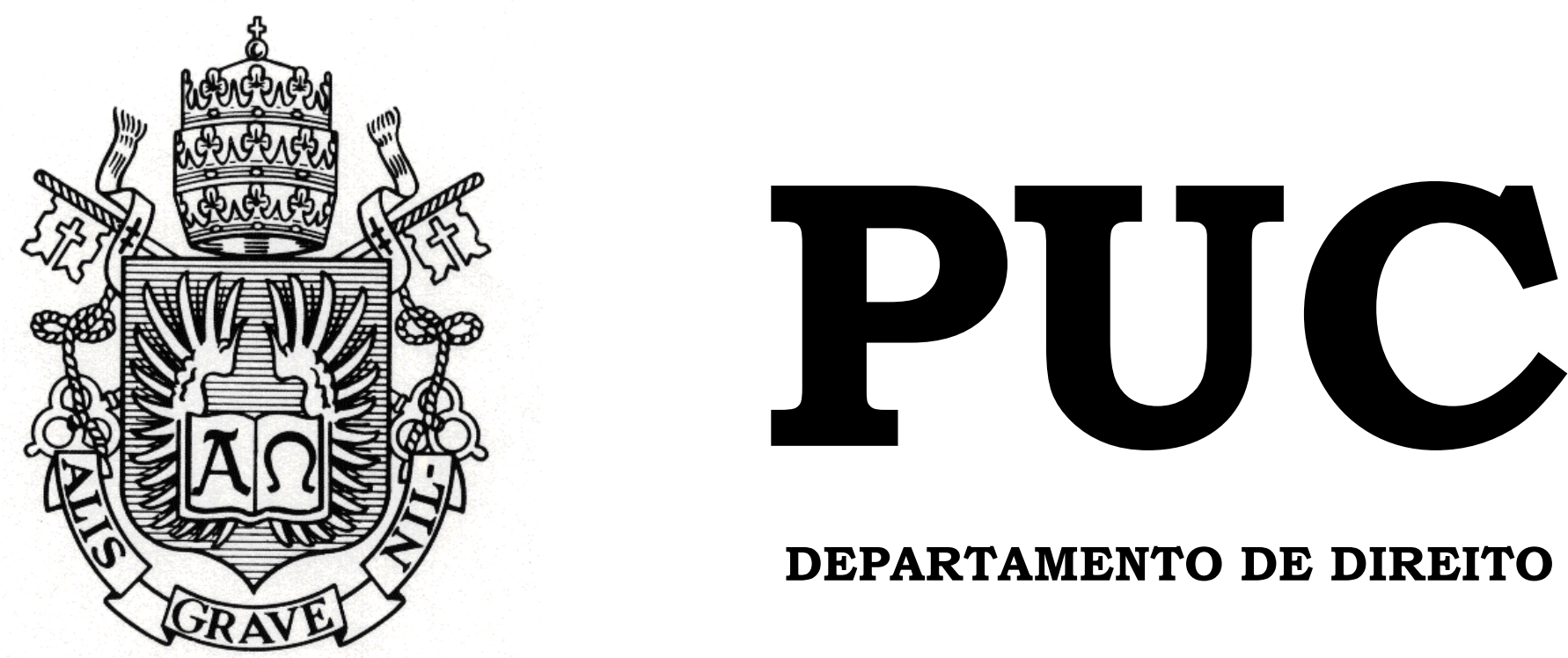

DEPARTAMENTO DE DIREITO

\title{
A SELETIVIDADE PENAL NA CRIMINALIZAÇÃO DAS DROGAS NA CIDADE DO RIO DE JANEIRO: APLICAÇÃO SUBJETIVA DO ARTIGO 33 DA LEI DE DROGAS
}

por

CAROLINA ZANINI FERREIRA

ORIENTADOR: SÉRGIO CHASTINET DUARTE GUIMARÃES 2019.1

PONTIFÍCIA UNIVERSIDADE CATÓLICA DO RIO DE JANEIRO RUA MARQUÊS DE SÃO VICENTE, 225 - CEP 22453-900 RIO DE JANEIRO - BRASIL 


\title{
A SELETIVIDADE PENAL NA CRIMINALIZAÇÃO DAS DROGAS NA CIDADE DO RIO DE JANEIRO: APLICAÇÃO SUBJETIVA DO ARTIGO 33 DA LEI DE DROGAS
}

\author{
por \\ CAROLINA ZANINI FERREIRA
}

Monografia apresentada ao Departamento de Direito da Pontifícia Universidade Católica do Rio de Janeiro (PUC-Rio) para a obtenção do Título de Bacharel em Direito.

Orientador(a): Sérgio Chastinet Duarte Guimarães. 


\section{Agradecimentos}

Agradeço aos meus pais, Claudio e Shirley, pelo total apoio e confiança em mim durante todo o período da faculdade de Direito. Agradeço, também, a minha irmã, Bruna, que sempre torceu pelo meu sucesso e sempre esteve comigo em todas as circunstâncias da vida. E, principalmente, agradeço a minha avó Hilda, que terá a oportunidade de ler este trabalho e meu avô Nery, que apesar da distância, me acompanhou por cada segundo e fez com que esse momento se tornasse possível.

Ao meu companheiro Thiago e sua família, por toda força e compreensão que podiam dar e a Isabella, amiga- irmã de infância que sempre acreditou no meu potencial.

Ao Pedro II, colégio em que estudei por 12 anos, e que me fez pensar o mundo de forma crítica, entender os espaços políticos e perceber a importância de ter consciência das desigualdades que me cerca.

Ao meu estágio no IV JECRIM do Leblon e, especialmente, ao Núcleo do Sistema Penitenciário da Defensoria Pública do Estado do Rio de Janeiro, pelo qual tomei um choque de realidade e tive certeza de que é preciso usar meus privilégios para lutar pelo o que acredito. Ao PIBIC de presunção de inocência da PUC-RIO, que me permitiu aprofundar o estudo sobre o Direito Penal.

Por último, ao meu orientador, Sérgio Chastinet Duarte Guimarães, por ter aceitado me orientar e por toda a dedicação e empenho que demonstra em suas aulas. Devo sempre aos seus ensinamentos, que me fizeram acreditar no meu amor pelo Direito Penal. 


\section{Resumo}

A presente monografia trata do impacto que a criminalização das drogas exerce no Brasil, mais especificamente, na cidade do Rio de Janeiro. Para este fim, investigamos como a formação de um estereótipo de traficante influencia na aplicação subjetiva do tipo de tráfico de drogas pela atual Lei de drogas. Usando o marco teórico da criminologia crítica, exploramos a principal função que a criminalização das drogas desempenha: a seletividade penal e a exclusão das classes subalternas. Com os números apresentados pelo Departamento Penitenciário Nacional, chegamos a uma conclusão: a Guerra às Drogas, na verdade é uma Guerra aos Pobres.

\section{Palavras-Chaves}

Criminalização; seletividade; estereótipo; traficante; usuário; criminologia; cárcere; Rio de Janeiro. 


\section{Sumário}

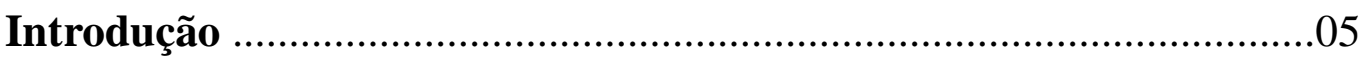

Capítulo 01: A cidade do Rio de Janeiro como cenário da guerra..............10

Capítulo 02: Sob o olhar da criminologia crítica.......................................15

Capítulo 03: A criminalização das drogas ..................................................23

3.1: Um breve histórico das legislações de drogas no Brasil...........23

3.2: A vigente legislação e as consequências da aplicação dos artigos

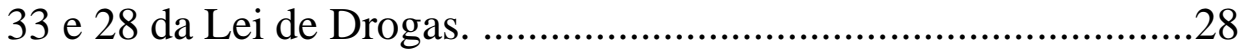

3.3: A aplicação subjetiva do artigo 33 da Lei de Drogas.................34

Capítulo 04: A principal função da criminalização das drogas...................50

4.1: O mito da proteção de um bem jurídico.......................................50

4.2: A principal função da criminalização das drogas.......................53

4.3: Os reflexos da criminalização no cárcere...................................59

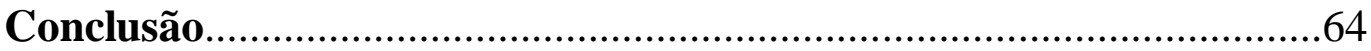

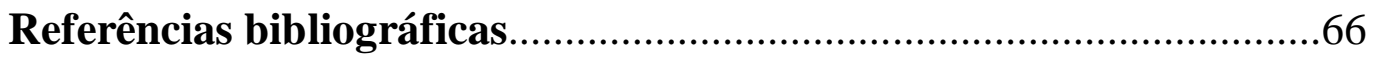




\section{Introdução}

Em todos os âmbitos da vida em sociedade, a punição é considerada uma das mais eficazes formas de controle e disciplina, seja na esfera privada, nos lares entre pais e filhos, seja na esfera pública, nas cadeias entre Estado e criminoso. Em época de tamanho punitivismo, é de extrema importância que não nos ceguemos sobre só e, exclusivamente, o que está positivado e previsto em Lei. É necessário olharmos através da criação das normas para entendermos o que se pretende com elas a partir do contexto histórico e social em que estamos inseridos, principalmente quando falamos de um país que escreveu sua história por meio de derramamento de sangue, aprisionamento e punição.

O Brasil é o terceiro país que mais encarcera no mundo ${ }^{1}$. Estima-se que dentre 206.081.432 de habitantes ${ }^{2}$ que moram no país, $726.712^{3}$ estão cumprindo algum tipo de pena no sistema carcerário, seja depois de uma condenação transitada em julgado ou como uma prisão cautelar. Neste contexto, há diversos autores que tentam decifrar o que acontece com o fenômeno do encarceramento em massa no Brasil.

Ainda que seja extremamente peculiar o modo pelo qual o governo e a sociedade brasileira encaram, de uma maneira geral, a necessidade de punição através da privação da liberdade, resultando nos números assustadores mostrados acima, há outros pontos também que merecem atenção. Um deles é o fato de que as cadeias brasileiras estão exercendo uma

\footnotetext{
${ }^{1}$ BRASIL. Ministério da Justiça. Departamento Penitenciário Nacional. Levantamento Nacional de Informações Penitenciárias. Infopen, junho de 2016. Disponível em: https://www.conjur.com.br/dl/infopen-levantamento.pdf. Acesso em: 13/06/2019.

${ }^{2}$ BRASIL. Instituto Brasileiro de Histótia e Geografia. Disponível em: <ftp://ftp.ibge.gov.br/Estimativas_de_Populacao/Estimativas_2016/estimativa_dou_2016_201609 13.pdf>. Acessado em: 01/06/2019.

${ }^{3}$ BRASIL. Ministério da Justiça. Departamento Penitenciário Nacional. Levantamento Nacional de Informações Penitenciárias. Infopen, junho de 2016. Disponível em: https://www.conjur.com.br/dl/infopen-levantamento.pdf. Acesso em: 01/06/2019.
} 
função de segregação da sociedade, o que fica visível quando pegamos os dados do Departamento Penitenciário Nacional (DEPEN) e analisamos que uma parte definida e determinada da população está sendo encarcerada. Essa parte da população é majoritariamente negra ${ }^{4}$, de classes sociais mais baixas, pouca ou nenhuma escolaridade ${ }^{5}$ e moradores de favelas e subúrbios, o que ficará demonstrado no final do trabalho.

Um outro ponto importante, é que quando vamos à investigação mais recente dos números produzidos pelo DEPEN do ano de 2016, percebemos que há uma incidência muito grande no encarceramento pelo cometimento de dois tipos de crime. O primeiro é o crime patrimonial ${ }^{6}$, principalmente no que tange o roubo e o furto, ambos previstos no Código Penal brasileiro, nos artigos 157 e 155, respectivamente. Por outro lado, temos o tráfico de drogas $^{7}$, previsto nos artigos 33 e seguintes da Lei 11.343/06, que será o objeto principal do presente trabalho.

Adentrando mais precisamente no contexto da cidade do Rio de Janeiro, que será o território cenário do estudo, percebemos que há uma guerra na qual figuram a polícia militar, de um lado, e os traficantes de drogas do outro. Esse cenário é fundamental para entendermos qual é a verdadeira função da criminalização das Drogas, uma vez que as forças do Estado ganham legitimidade e carta branca para adentrar nos territórios que são conhecidos por serem "dominados" pelo tráfico, como é o caso das favelas e subúrbios, se utilizando de investidas truculentas contra os moradores e os próprios criminosos.

\footnotetext{
${ }^{4}$ BRASIL. Ministério da Justiça. Departamento Penitenciário Nacional. Levantamento Nacional de Informações Penitenciárias. Infopen, junho de 2016. Disponível em: https://www.conjur.com.br/dl/infopen-levantamento.pdf. Acesso em: 01/06/2019

${ }^{5}$ BRASIL. Ministério da Justiça. Departamento Penitenciário Nacional. Levantamento Nacional de Informações Penitenciárias. Infopen, junho de 2016. Disponível em: https://www.conjur.com.br/dl/infopen-levantamento.pdf. Acesso em: 01/06/2019

${ }^{6}$ BRASIL. Ministério da Justiça. Departamento Penitenciário Nacional. Levantamento Nacional de Informações Penitenciárias. Infopen, junho de 2016. Disponível em: https://www.conjur.com.br/dl/infopen-levantamento.pdf. Acesso em: 01/06/2019.

${ }^{7}$ BRASIL. Ministério da Justiça. Departamento Penitenciário Nacional. Levantamento Nacional de Informações Penitenciárias. Infopen, junho de 2016. Disponível em: https://www.conjur.com.br/dl/infopen-levantamento.pdf. Acesso em: 01/06/2019.
} 
É importante frisar que todas essas investidas do governo - e que os governantes chamam de políticas públicas - são televisionadas, de modo que as massas midiáticas exercem um papel fundamental para construir um senso comum irresponsável e completamente tendencioso, principalmente quando o telespectador é aquele que não está inserido diretamente na conjuntura dessa guerra ${ }^{8}$. Através das informações tortas e parciais, da formação deste senso comum e da demonização de parte determinada da sociedade, surge uma figura que vai ser de suma importância para o presente estudo: o traficante de drogas, que assume o papel de inimigo ${ }^{9}$ da população.

A grande questão é justamente indagar se são somente esses territórios, onde vivem pessoas das classes mais baixas e com menos escolaridade, que se encontra o tráfico de drogas e a própria figura do traficante. Será então que na Zona Sul do Rio de Janeiro não tem tráfico? Será que não tem traficante? É a partir desses questionamentos que surge afirmação de uma seletividade penal, exercida tanto pelas instâncias informais, que seriam as famílias, a escola, a opinião pública, quanto pelas formais que seriam os legisladores, o Poder Judiciário, o Ministério Público, as instituições penitenciárias e a própria polícia ${ }^{10}$.

Seria de grande ingenuidade pensar que a seletividade é exercida apenas através das forças estatais ou somente no instante em que há o primeiro contato da autoridade policial com o agente. Quando o suposto criminoso chega na delegacia, a seletividade continua a ser perpetuada. A partir desse momento, e de modo geral, poderão acontecer duas coisas: ou o Delegado de Polícia tipificará o indivíduo nos artigos 33 e seguintes da Lei 11.343/06, ou no artigo 28 da mesma Lei. Apesar de ambos serem crimes, as consequências são extremamente diferentes. Enquanto o usuário assina um

\footnotetext{
${ }^{8}$ BATISTA, Vera Malaguti. Difíceis ganhos fáceis: drogas e juventude pobre no Rio de Janeiro. Instituto Carioca de Criminologia, 2003, p.24.

${ }^{9}$ ZAFFARONI, Eugenio Raúl. O inimigo no direito penal. Revan, 2007, p.18.

${ }^{10}$ MOLINA, Antonio García-Pablos de \& GOMES, Luiz Flávio. Criminologia. 4. ed. São Paulo: Editora revista dos tribunias, 2002, p. 134.
} 
termo circunstanciado, o traficante encara uma prisão em flagrante, e na grande maioria das vezes, é apenado com uma pena privativa de liberdade.

O mesmo ocorre quando o Ministério Público oferece a denúncia, e mais tarde, mas não menos importante, na ocasião em que o Juiz a recebe e condena o agente. Destaca-se que a autoridade policial não é quem atribui, definitivamente, qual a imputação do crime que o autor cometeu. $O$ Ministério Público, ao fazer a denúncia, pode modificar a tipificação, assim como o juiz não está obrigado a seguir estritamente o que está na peça inicial do parquet, se mediante algum fato ou aspecto jurídico, entender o contrário. Isso é importante pois a cada fase que o sujeito passa para ser condenado, há uma seletividade exercida por atores diferentes, desde o momento em que o agente é acusado, até o momento em que é condenado, e indo mais além, até o final do cumprimento de sua pena.

É preciso entender que a seletividade não surge no momento em que o sujeito é detido, mas sim a partir do momento em que ele nasce, dependendo de suas condições sociais, como se estivesse condenado somente pelo fato de morar em um território visto como perigoso ou simplesmente pela cor de sua pele. Com a formação dos estereótipos, se constrói a figura do traficante, o que importará em sua qualificação como usuário ou traficante em momento posterior.

Então, o presente trabalho visa analisar o que está por trás da diferenciação na aplicação do artigo 33, referentes ao tráfico de drogas, ou do artigo 28, referente ao uso de drogas, pelo magistrado. Para tanto, serão examinados quais os critérios e os fundamentos por trás dessa aplicação, uma vez que a distinção do tráfico para o uso, não está relacionada a parâmetros objetivos e quantitativo, mas diz respeito tão somente a aspectos subjetivos em relação ao indivíduo e as circunstâncias em que este está inserido. Assim, também será demonstrado, a partir dos números colhidos pelo DEPEN, qual é o perfil dos traficantes que estão sendo encarcerados. 
Por conseguinte, chegaremos na principal função da criminalização das drogas e para tal, observaremos qual é o genuíno papel que cumpre a penalização através da privação da liberdade, pena mais rigorosa prevista no nosso Código Penal. Para esta tarefa, será necessário explorar alguns tópicos, como: O Rio de Janeiro como cenário ideal para uma "Guerra às Drogas"; se o argumento da proteção de um bem jurídico é razoável para justificar a criminalização; o papel que a formação dos estereótipos cumpre na seletividade penal e na criminalização.

Esse exame será feito a partir do marco teórico da criminologia crítica, a qual defende que o crime não é um fenômeno ontológico, quebrando o paradigma etiológico da antiga escola positivista. A partir da criminologia crítica, o crime, o criminoso, a construção da criminalidade e a questão criminal são diretamente influenciados por um aspecto econômico-social, que tem como base uma relação de dominação exercida pela lógica do trabalho e do capital.

Embora esse tema já tenha sido estudado e investigado por diversos autores, a sua importância aumenta cada vez mais. A polícia do Rio de Janeiro é a que mais mata e a que mais morre. Os presídios estão recebendo cada vez mais detentos, independentemente de condenação. As decisões judiciais cada vez mais são decisões automáticas, com argumentos morais, repletas de preconceito e estereótipos. A população pobre e negra está sendo dizimada. A única solução que o governo encontra para combater o tráfico de drogas nas favelas é a morte, com o escudo do auto de resistência. As vidas nas favelas importam. Enquanto não desmistificarmos a Droga como desculpa para empilhar corpos marcados dentro de cadeias que não têm a menor condição estrutural, psicológica ou de qualquer outra função que se propõe a realizar, esse tema continuará sendo de suma importância, e é por isso que foi escolhido para ser fruto desde trabalho. 


\section{Capítulo 01: A cidade do Rio de Janeiro como cenário da guerra}

A cidade do Rio de Janeiro foi escolhida para retratar a guerra contra as drogas por revelar peculiaridades que nenhuma outra cidade nos mostrou. Cenário de uma desigualdade social vista e experimentada pelos moradores que a habitam, a cidade maravilhosa hoje é palco de uma guerra que atingiu níveis de homicídio semelhantes a guerra na Síria ${ }^{11}$.

Para compreendermos minimamente a conjuntura dessa guerra e a sua relação com a cidade do Rio de Janeiro, primeiro precisamos entender que a cidade é dividida em diversas zonas: Zonal Sul, Zona Norte, Zona Oeste e Centro. A divisão não corresponde tão somente ao critério geográfico, mas também e, principalmente, ao critério econômico. Enquanto a Zona Sul é a zona em que compreende um dos metros quadrados mais caros do mundo, comportando as famílias de alta renda, na Zona Norte e Oeste, acomodamse, majoritariamente, os indivíduos com condições financeiras inferiores.

A importância dessa distinção será analisada quando investigarmos que um dos critérios para a distinção entre o usuário e o traficante, é justamente o local onde mora. A distribuição de renda na cidade do Rio de Janeiro é mais complexa do que essa mera divisão de zonas, uma vez que diversas favelas e comunidades se encontram também na Zona Sul, figurando nas belas imagens impressas nos cartões postais, mas que não saem ilesas quando se trata de violência.

Por meio de um aplicativo de celular "Onde Tem Tiroteio", criado para avisar aos usuários onde acontecem os confrontos armados em tempo

\footnotetext{
${ }^{11}$ O GLOBO. Números da violência no Rio se assemelham aos de países em guerra. Globo.com (Jornal Nacional), 09 de maio de 2017.Disponível em:http://g1.globo.com/jornalnacional/noticia/2017/05/numeros-da-violencia-no-rio-se-assemelham-aos-de-paises-emguerra.html.Acessado em:10/06/2019.
} 
real, enxergamos que somente lugares específicos são palcos de guerra ${ }^{12}$. No ano de 2018, dos 05 bairros com mais tiroteios na cidade do Rio de Janeiro, apenas um fica na Zona Sul da cidade. A liderança está com a Cidade de Deus, comunidade na Zona Oeste, seguido da Praça Seca na mesma Zona. Na Zona Norte temos o Jacarezinho e na Zona Sul, representando o único bairro, está a Rocinha, a maior favela do Brasil, ocupando 95 hectares que servem de moradia para quase 70 mil pessoas. ${ }^{13}$

Essa conjuntura se reflete nas "políticas públicas" adotadas pelo governo do Estado do Rio de Janeiro que pretendem, legitimamente, trucidar as classes mais baixas que vivem nesses bairros e comunidades. Não é de hoje que os governantes colocam em prática ações que pretendem excluir e neutralizar essa população, que segundo o Censo de 2010 do IBGE, são representadas por $22 \%$ do total da cidade, fazendo da capital fluminense o munício brasileiro com o maior número de moradores em favelas: 1.393.314 habitantes ${ }^{14}$.

A formação dessas favelas e dos bairros mais pobres e carentes da cidade teve influência direta na escravidão. No Brasil, diferentemente do que ocorreu na Europa, a construção de uma burguesia se deu através da colonização e do modo de produção escravista que desenvolveu uma realidade na qual o escravo era mera mercadoria ${ }^{15}$.

Esse fato se torna importante porque foi no período da dissolução das relações escravistas junto a políticas de migração, que se criaram nas cidades

\footnotetext{
${ }^{12}$ GRELLET, F. Tiroteios no Rio migram da zona norte para a oeste. Brasil.estadão.com, 25 de fevereiro de 2018. Disponível em:https://brasil.estadao.com.br/noticias/rio-de-janeiro,tiroteios-norio-migram-da-zona-norte-para-a-oeste,70002204071. Acesso em: 10/06/2019.

${ }^{13}$ O GLOBO. Rocinha: maior favela do país. Globo.com, 17 de setembro de 2018. Disponível em: https://oglobo.globo.com/rio/rocinha-maior-favela-do-pais-21834104. Acesso em: 10/06/2019.

${ }^{14}$ Observatório Legistativo da Intervenção Federal na Segurança Pública do Rio de Janeiro. Favelas cariocas. Disponível em:http://olerj.camara.leg.br/retratos-da-intervencao/favelas-cariocas. Acesso em: 10/06/2019.

${ }^{15}$ BATISTA, Vera Malaguti. Difíceis ganhos fáceis: drogas e juventude pobre no Rio de Janeiro. Instituto Carioca de Criminologia, 2003, p.38.
} 
brasileiras, contingentes de homens negros, escravos e libertos. Como assinala Vera Malaguti:

No fim do século XIX, há um temor dessa mobilidade contínua chamado de "medo branco de almas negras" por Sidney Chalhoub. Esta população de escravos e libertos, entre 1830 e 1870, institui o processo de formação da cidade negra. No censo de 1849, o Rio de Janeiro tem a maior população escrava negra das Américas. A preocupação com a segurança se traduz em todos os níveis. O medo branco faz com que o temor à insurreição seja mais sólido que a própria perspectiva de insurreição ${ }^{16}$.

A então cidade negra passou a ser alvo das mais diversas políticas de controle social e urbana, que atacaram a memória histórica do que a cidade representava.

No Rio de Janeiro as intervenções urbanas têm uma concepção higienista. Pereira Rego propõe uma cirurgia na cidade com esvaziamento do centro e remoção dos bairros pobres para áreas periféricas. Rodrigues Alves desenvolve a primeira intervenção sistemática do Estado sobre o espaço urbano no Rio de Janeiro, demolindo milhares de cortiços para grandes obras urbanísticas ${ }^{17}$.

Outra intervenção foi dirigida por Pereira Passos, então prefeito da cidade, que ordenou a demolição de centenas de cortiços e favelas para criar nosso "Haussmann tropical", expressão utilizada por Vera Malaguti para se referir a uma imitação das ruas largas de Paris com jardins projetados pelo urbanista francês Georges-Eugène Haussmann. Com esse breve apanhado histórico, conclui-se que o processo de urbanização na cidade do Rio de Janeiro é o retrato fiel da sua visão de cidadania: a exclusão permanente das classes subalternas ${ }^{18}$.

Como no século XIX, o Rio de Janeiro ainda é alvo de políticas públicas que se colocam como medidas necessárias de segurança e combate ao tráfico de drogas. É o caso da implementação das Unidades de Polícia Pacificadoras (UPPs) e da recente Intervenção Federal nas comunidades do Rio. Se fez uma enorme propaganda de ambas as medidas com promessas de acabar com a violência e com o medo na cidade, porém, desde a primeira

\footnotetext{
${ }^{16}$ BATISTA, Vera Malaguti. Difíceis ganhos fáceis: drogas e juventude pobre no Rio de Janeiro. Instituto Carioca de Criminologia, 2003, p.39.

${ }^{17}$ BATISTA, Vera Malaguti. Difíceis ganhos fáceis: drogas e juventude pobre no Rio de Janeiro. Instituto Carioca de Criminologia, 2003, p.39.

${ }^{18}$ BATISTA, Vera Malaguti. Difíceis ganhos fáceis: drogas e juventude pobre no Rio de Janeiro. Instituto Carioca de Criminologia, 2003, p.40.
} 
Unidade de Pacificação construída e a realização da Intervenção, os índices de morte e violência não diminuíram, pelo contrário.

Sob intervenção, o Rio tem o maior número de mortos por policiais em $16 \operatorname{anos}^{19}$, considerando que somente em 2018, ocorreram 558 mortes por intervenção de agentes do Estado ${ }^{20}$. Ainda, de acordo com o Observatório Legislativo da intervenção Federal na Segurança Pública do Rio de Janeiro:

O número de mortes por intervenção policial mais que dobrou nos últimos cinco anos. Entre janeiro e julho de 2013, 236 pessoas morreram em ações da polícia no Rio de Janeiro. Nos sete primeiros meses de 2018, ocorreram 895 mortes, um aumento de $279 \%$. A média mensal que era de 33 mortes passou para 127 . O Rio abriu o ano de 2018 com 157 mortes por intervenção policial ainda em janeiro. Foi o mês com maior número de mortes desde 1998, quando o Instituto de Segurança Pública começa a monitora e registrar os índices. Especialistas apontam que o número de mortes aumenta na medida em que as intervenções policiais e militares se intensificam ${ }^{21}$.

E mesmo com tantos números, de diversas pesquisas e coletas de dados diferentes, mostrando que as políticas públicas de controle e fiscalização da sociedade não resolvem o problema da violência e da "criminalidade", o atual governador do Rio de Janeiro contratou Snipers para "abater bandidos armados" nas favelas.

O interessante é que com a concentração de investidas estatais em áreas como favelas e bairros mais carentes, permite-nos pensar que somente há tráfico e traficante nesses lugares determinados. Mas assumir que o governo somente está mostrando sua força nesses espaços para combater a violência e a criminalidade, é negar que há pessoas ricas traficando drogas nos condomínios da zona sul. É negar também que há uma seleção de quem

\footnotetext{
${ }^{19}$ Folha de São Paula. Sob intervenção, Rio tem maior número de mortos por policiais em 16 anos. Disponível em:https://www1.folha.uol.com.br/cotidiano/2018/12/sob-intervencao-rio-temmaior-numero-de-mortos-por-policiais-em-16-anos.shtml. Acessado em: 10/06/2019.

${ }^{20}$ Instituto se Segurança Pública (ISP). Séries históricas anuais de taxa de letalidade violenta no estado do Rio de Janeiro e grandes regiões, março de 2019. Disponível em: http://www.ispdados.rj.gov.br/Arquivos/SeriesHistoricasLetalidadeViolenta.pdf. Acessado em: 10/06/2019.

${ }^{21}$ Observatório Legistativo da Intervenção Federal na Segurança Pública do Rio de Janeiro. Violência e Intervenção Federal. Disponível em: http://olerj.camara.leg.br/retratos-daintervencao/violencia-e-intervencao-policial. Acessado em: 10/06/2019.
} 
será controlado e punido. E, principalmente, é negar que a população branca e rica da zona sul é privilegiada.

Todas essas particularidades tornam a cidade do Rio de Janeiro um cenário inigualável para demonstrar a seletividade penal. Nessa cidade, o considerado e visto como traficante do mal tem cor, renda, e endereço definido. Não diferente é o traficante do bem, que tem tudo isso e mais um pouco: é tratado como usuário. 


\section{Capítulo 02 - Sob o olhar da criminologia crítica}

É indiscutível a importância de traçar um marco teórico para embasar os argumentos e definir o caminho que será percorrido pelo presente trabalho. O objeto em questão é tratado por diversas áreas do saber como a psicologia, a ciência política, antropologia, história e sociologia, uma vez que quando tratamos de tráfico, drogas e seletividade penal, estabelecemos uma relação direta com questões referentes à política, saúde pública, formação e desenvolvimento da sociedade. É a partir desse aspecto pluridisciplinar que observamos a total influência da criminologia.

Embora haja divergência dos autores quanto a definição dessa matéria, Raúl Zaffaroni em seu livro ${ }^{22}$, afirma de forma muito curiosa e inovadora que a criminologia é "o curso dos discursos sobre a questão criminal". O discurso seria uma ferramenta criada para explicar (ou tentar) os fenômenos que o próprio homem já encarou na história da humanidade - e continuará encarando enquanto houver vida. Se existem fenômenos de diferentes naturezas, respectivamente existirão discursos de diferentes naturezas. Nesse sentido, o discurso seria uma apropriação da realidade pelo ser humano. Este fato nos permite compreender quais fenômenos sociais e econômicos deram origem aos discursos das mais diversas escolas criminológicas existentes até então.

A teoria utilizada como base teórica do presente trabalho, é a criminologia crítica. Para entendermos como essa linha criminológica trabalha o tema em questão, é necessário primeiro voltarmos no tempo e revisitarmos brevemente os discursos adotados principalmente pelas escolas

\footnotetext{
${ }^{22}$ ZAFFARONI, Eugenio Raúl. Criminologia: aproximacion desde un margen. Bogotá:Temis, 1998
} 
liberal clássica e a positivista, esta última que ainda exerce grande influência nos dias de hoje.

O objetivo aqui não é expor os motivos que levaram ao surgimento da criminologia crítica, tampouco é analisar a fundo como se deu a formação da Escola liberal clássica ou da Escola positivista. O foco é demonstrar como essas escolas dos séculos passados se contrapõem ao que os autores chamaram de criminologia crítica, e mais importante ainda é mostrar como esses discursos tão conservadores e adotados abertamente pela sociedade daquela época, deixaram rastros no século XXI.

A partir do século XVI, se vivenciava um contexto histórico na Europa que levou à ampliação do conhecimento em relação à vida, à existência, e ao que é o mundo, culminando em grandes transformações. Há dois grandes movimentos que foram elementares nesse momento: a reforma protestante $\mathrm{e}$ o renascimento cultural. A reforma protestante levou ao rompimento da igreja católica e consequentemente, o surgimento do anglicanismo na Inglaterra. Já o renascimento, recupera uma série de conceitos e princípios no campo das artes e da cultura, que haviam sido abandonados e esquecidos por um longo período. A partir dessa dinâmica, o conceito de indivíduo foi construído, atribuindo uma individualidade ao ser humano que antes era entendido como uma criatura de Deus.

Esse deslocamento de compreensão acerca da individualidade do ser, ameaça uma ordem política, porque a partir dessa nova perspectiva, a igreja católica tem cada vez menos poder. Aquela burguesia do início dos séculos anteriores, começa a se definir contendo interesses não somente no lucro e na acumulação do capital, mas passa a vislumbrar a possibilidade de ter um projeto próprio de sociedade.

Essas mudanças desencadearam, no século XVII, diversas revoluções. Com isso, surge a figura do contrato social, inicialmente com Hobbes e Locke. Hobbes diz que existe um estado de natureza de forma individual. Porém, neste estado de natureza, o indivíduo oferecia perigo para os demais 
habitantes da mesma sociedade, o que ocasionaria uma guerra entre eles. Então, o ser humano, deveria firmar um acordo colocando todos os desejos, direitos e faculdades na mão do monarca, figura responsável por administrar esses sentimentos $^{23}$. Esse acordo foi conhecido como o contrato social. Locke se apropria do conceito de contrato social e a sistemática utilizada pelo Hobbes, mas entende que o estado de natureza é bom e traz a ideia de parlamento. Esses contratualistas são precursores para os autores do Iluminismo do século XVIII.

Beccaria, no ano de 1764, influenciado pela noção de contratualismo dos escritores mencionados acima, escreve "Dos delitos e das Penas", inaugurando a reforma liberal em que a Escola clássica passou a considerar o direito penal e a pena, como um instrumento legal para defender a sociedade do crime, encontrando limites na necessidade, utilidade e legalidade, não podendo as penas justificar uma vingança. Podemos entender essa função do delito quando Baratta ilustra que:

a escola clássica liberal se detinha principalmente sobre o delito, entendido como o conceito jurídico, isto é, como violação do direito e, também, daquele pacto social que estava, segundo a filosofia política do liberalismo clássico, na base do Estado e do direito. Como comportamento, o delito surgia da livre vontade do indivíduo, não de causas patológicas, e por isso, do ponto de vista da liberdade e da responsabilidade moral pelas próprias ações, o delinquente não era diferente, segundo a Escola clássica, do indivíduo normal ${ }^{24}$.

Apesar da Escola clássica liberal ter rompido com o antigo modelo absolutista inquisitorial, no início do séc XX, a escola positivista ganha força e traz um novo panorama, completamente absorvido pela sociedade da época, que colhe seus resquícios até hoje.

Diferentemente do que pensa a escola clássica, em que o delito é um ente juridicamente qualificado e que surge pelo ato da livre vontade do

\footnotetext{
${ }^{23}$ ANITUA, Gabriel. História dos pensamentos criminológicos. Rio de Janeiro, Editora Revan: 2008, p. 127.

${ }^{24}$ BARATTA, Alessandro. Criminologia Crítica e Crítica do Direito Penal: introdução à sociologia do direito penal. Coleção Pensamento criminológico. Rio de Janeiro, Editora Revan, 6 . Edição 2011, p. 31.
} 
sujeito, para a escola positivista há a separação entre o sujeito que tem o conhecimento e o objeto a ser estudado. Ou seja, para o positivismo, o delito é natural, é parte da personalidade da pessoa, o que contrapõe à ideia liberal de responsabilidade moral. Nas palavras de Rosa del Olmo, a escola positivista "foi uma reação, dentro das próprias ciências penais contra o individualismo, fruto da filosofia do século XVIII, em favor do determinismo" 25 .

Como observado, houve uma ruptura com o pensamento liberal. A sociedade passou a usar a ciência como explicação de todos os fenômenos. Diante da experiência da revolução industrial, houve um grande lema instaurado e absorvido pela sociedade: "ordem e progresso", no qual a ciência foi exatamente o instrumento utilizado pela burguesia não só para atingir esse progresso, mas principalmente, para mantê-lo. O discurso científico era a nova religião ${ }^{26}$ e buscava a legitimação do poder punitivo contra os perigos do proletariado.

Era necessária uma nova ciência - a ciência do homem e da sociedade - que pudesse controlar a população e manter a ordem, ao passo que impedia o regresso às antigas formas de governo. Destaca-se, nesse contexto, que o positivismo surge no medo das revoluções populares. Ainda de acordo com Rosa del Olmo:

A revolução burguesa precisava, de um lado, defender-se de toda tentativa de restaurar o passado e, de outro, garantir a ordem social reinante, defendendo-se do proletariado em ascensão. A ciência seria chamada a encontrar o ordenamento racional dos fenômenos, mas atendendo-se ao que os fatos observáveis expressavam. ${ }^{27}$

O impedimento da ordem e do progresso vivenciados no momento, era atrelado diretamente à uma relação de capital e força de trabalho e,

\footnotetext{
${ }^{25}$ DEL OLMO, Rosa. A América Latina e sua criminologia. Rio de janeiro, Editora Revan, 2004, p.39.

${ }^{26}$ DEL OLMO, Rosa. A América Latina e sua criminologia. Rio de Janeiro, Editora Revan, 2004, p. 37.

${ }^{27}$ DEL OLMO, Rosa. A América Latina e sua criminologia. Rio de Janeiro, Editora Revan, 2004, p. 36.
} 
portanto, a ciência exercia uma função de neutralizar essas frentes, com medidas legais, para que não houvesse nenhum tipo de importuno nas pretensões da burguesia. Segundo Vera Malaguti ${ }^{28}$, nesse contexto, a prisão se institui como controle punitivo das movimentações de uma população que servia de mão de obra nas fábricas durante a revolução industrial.

A partir da necessidade de neutralização e desumanização dessa massa proletária que se movimentava no sentido contrário aos interesses burgueses, surgiu a criminologia como ciência. A obra que instaurou a criminologia positivista foi "L'uomo Delinquente" de Cesare Lombroso, publicada em 1876, pautada em um determinismo biológico que acentuava as características do delito como elemento indicativo da personalidade do autor, o que significa dizer que a delinquência seria determinada biologicamente. $\mathrm{O}$ método utilizado por Lombroso foi a classificação da população carcerária da época, relacionando a causalidade do comportamento criminal às características físicas dos pobres e indesejáveis que se encontravam nas prisões $^{29}$. Consequentemente, na sociedade positivista, a burguesia não cometia crimes, uma vez que não era o público encarcerado.

No decorrer do tempo, a teoria positivista começou a ser severamente questionada, ocasionando uma mudança paradigmática diante do surgimento de novas teorias criminológicas. A ideia de um crime ontológico e um criminoso natural deixa de existir abrindo espaço para uma concepção sociológica. Para traçar o caminho percorrido pelas novas escolas sociológicas, Baratta analisou que em primeiro lugar, houve um enfoque teórico para as condições objetivas, estruturais e funcionais, que estão na origem do desvio. Logo depois, o enfoque foi direcionado para os mecanismos sociais e institucionais que criam a definição de desvio e, por conseguinte, a criminalidade e os processos de criminalização:

\footnotetext{
${ }^{28}$ BATISTA, Vera Malaguti. Introdução crítica à criminologia brasileira. Rio de Janeiro: Revan, 2011, p.42.

${ }^{29}$ BATISTA, Vera Malaguti. Introdução crítica à criminologia brasileira. Rio de Janeiro: Revan, 2011, p.45.
} 
Substituindo a pretendida dimensão biopsicológica do fenômeno criminal pela dimensão sociológica, as teorias integrantes da criminologia liberal contemporânea inverteram a relação da criminologia com a ideologia e a dogmática penal. Elas sustentaram o caráter normal e funcional da criminalidade (teoria funcionalista), a sua dependência de mecanismos de socialização a que os indivíduos estão expostos, não em função de pretensos caracteres biopsicológicos, mas de estratificação social (teoria das subculturas); deslocaram cada vez mais a atenção do comportamento criminoso para a função punitiva e para o direito penal (teoria psicanalítica da sociedade punitiva), para os mecanismos seletivos que guiaram a criminalização e a estigmatização de determinados sujeitos (teoria do labeling approach $)^{30}$.

Das linhas teóricas sociológicas que romperam com os laços positivistas, a teoria do labeling approach foi, sem dúvidas, a mais importante para a criminologia crítica. Essa teoria defende a noção de que o crime e o criminoso são construídos socialmente a partir de ações das instâncias oficiais de controle social. A “criminalidade" se torna uma etiqueta atribuída a determinados indivíduos que a sociedade entende como criminosos e delinquentes. O comportamento desviante é aquele definido e delimitado como tal, acarretando na formação de um estigma de criminoso para determinado grupo social. Com a ruptura sociológica, observamos um momento de transição da criminologia tradicional, com ideais liberais para a criminologia crítica, com ideais marxianos.

A criminologia crítica supera o paradigma etiológico. Ou seja, a partir desse marco teórico não há mais a investigação da causa da criminalidade. Consequentemente, há a superação do "desvio e da criminalidade como realidade ontológica preexistente à reação social e institucional" 31 .

Georg Rusche foi o primeiro a analisar a questão criminal e relacionála com as condições sociais e o mercado de trabalho, a partir do marco teórico marxista $^{32}$. Nesse sentido, entende-se que foi sua obra que deu fruto à criminologia crítica, tendo em vista essa nova perspectiva, cujo os processos

\footnotetext{
${ }^{30}$ BARATTA, Alessandro. Criminologia Crítica e Crítica do Direito Penal: introdução à sociologia do direito penal. Coleção Pensamento criminológico. Rio de Janeiro, Editora Revan, $6^{a}$. Edição 2011, p.148.

${ }^{31}$ BARATTA, Alessandro. Criminologia Crítica e Crítica do Direito Penal: introdução à sociologia do direito penal. Coleção Pensamento criminológico. Rio de Janeiro, Editora Revan, $6^{\text {a }}$. Edição 2011, p.161.

${ }^{32}$ KIRCHHEIMER, Otto; RUSCHE, Georg. Punição e estrutura social. Rio de Janeiro: Revan, 2004.
} 
de criminalização são filtrados por uma seletividade penal, na qual a luta de classes exerce um papel fundamental.

Como antes exposto, em meados do século XVIII, a sociedade vivenciava a revolução industrial, fenômeno que demandou uma migração forçada dos campos e dos feudos para as novas cidades. A partir da nova experiência científica e tecnológica, as fábricas se encontravam a todo vapor, com cada vez mais trabalhadores. O contingenciamento provocou, por outro lado, um exército industrial de reserva, composto pela massa proletária: uma massa de pobres sem trabalhos, sem perspectivas de recrutamento pela indústria e, principalmente, sem a capacidade de construir sua consciência de classe $^{33}$

Com base na criminologia crítica, é a partir desse momento que surge o discurso criminológico, como uma ciência burguesa motivada pela incansável acumulação do capital, com a finalidade de exercer um controle social sobre a massa produtora da mais-valia e a reserva industrial. $\mathrm{O}$ direito penal, então, aparece como um instrumento legitimante do discurso de classe que pretende a hegemonia do capital. Na lição de Vera Malaguti:

O processo punitivo estaria intrinsecamente ligado ao controle e disciplinamento do mercado de trabalho. A sanção penal teria então um vínculo direto com a força de trabalho e com o exército industrial de reserva ${ }^{34}$.

O marco teórico em questão assume uma quebra de paradigma na medida em que insere o capitalismo e, consequentemente, a forma como é produzido o capital, na origem e na manutenção do processo de criminalização. Seria afirmar que a questão criminal é um instrumento utilizado pela burguesia, até os dias de hoje, com o fim de legitimar a posição de dominação dessa classe, em detrimento dos trabalhadores, classe ora dominada.

\footnotetext{
${ }^{33}$ BATISTA, Vera Malaguti. Introdução crítica à criminologia brasileira. Rio de Janeiro: Revan, 2011, p. 82.

${ }^{34}$ BATISTA, Vera Malaguti. Introdução crítica à criminologia brasileira. Rio de Janeiro: Revan, 2011, p. 81.
} 
A afirmação de que o direito penal é um instrumento de legitimação da manutenção desse status quo, é o que baseia toda a tese da seletividade penal analisada por esse trabalho. Empregando essa alegação ao objeto do presente estudo, a criminalização das drogas, exercendo o papel de instrumento do direito penal, seria uma forma de legitimação, por parte do Estado brasileiro, da seletividade da população.

Quando há a criminalização de uma conduta, essa criminalização atinge um grupo específico e determinado de pessoas. O que existe é uma conduta tipificada voltada para a personalidade de alguém, e não a personalidade de alguém voltada para essa conduta. Nesse ponto de vista, o que chamamos de "guerra às drogas" 35 , na verdade é uma guerra aos pobres.

Portanto, no campo teórico, a criminologia crítica vem quebrar os paradigmas mais enraizados na população atém então, oriundos da escola positivista. Atribuindo à criminalização um elemento de interesse econômico e social, a criminologia de bases marxianas desmascara quais as pretensões da escola da burguesia até então. O grande problema que nos cerca, é que mesmo no século XXI, ainda observamos claramente a aplicação dos discursos da escola positivista.

A materialização desse discurso determinista é notada quando um dos requisitos a serem analisados para fins de penalização, é justamente as circunstancias sociais e pessoais em que o agente está inserido. Esse argumento será a base para a seletividade penal e a diferenciação da aplicação do artigo 28 e do artigo 33 da Lei de Drogas, que criminaliza o usuário e o traficante, respectivamente.

\footnotetext{
${ }^{35}$ Expressão criada por Nixon, ex-presidente dos EUA, no fim dos anos 60.
} 


\section{Capítulo 03 - A criminalização das drogas}

\section{1 - Um breve histórico das legislações de drogas no Brasil}

Para analisarmos a seletividade no artigo que tipifica o tráfico de drogas, é necessário, primeiramente, entendermos como o Brasil começou a criminalizar essa prática. Para tal, será feita breve referência aos modelos sanitário e bélico, denominados por Nilo Batista ${ }^{36}$, que demonstram a partir de uma cronologia das legislações, a origem do que conhecemos hoje como a Lei de Drogas (L.11.343/06).

O primeiro contato que o Brasil teve com algum tipo de punição pelo uso e comércio de substâncias tóxicas, foi com as Ordenações Filipinas ${ }^{37}$, vigente do ano de 1603 a 1830, quando entrou em vigor o Código Penal brasileiro do Império ${ }^{38}$. No código imperial, não havia nenhuma proibição no que diz respeito ao uso ou comércio de entorpecentes, o que mudou em 1890, com o Código ${ }^{39}$ instituído pela República. Observando o artigo 159, do código vigente, que criminalizava a conduta de: "expor à venda, ou ministrar, substâncias venenosas sem legítima autorização e sem as formalidades prescriptas nos regulamentos sanitários", concluímos que o governo pretendeu proteger o bem jurídico da "tranquilidade pública". Até esse momento, não havia uma criminalização ampla, mas sim um artigo voltado aos boticários ${ }^{40}$.

\footnotetext{
${ }^{36}$ BATISTA, Nilo. Política criminal com derramamento de sangue. Discursos sediciosos, v. 3, n. 5-6, p. 77-94, 1998.

37 BRASIL. Ordenações Filipinas, Título LXXXIX. Disponível em: https://www.diariodasleis.com.br/tabelas/ordenacoes/1-274-103-1451-04-05-89.pdf. Acesso em: 31/05/2019.

38 BRASIL. Código Penal de 1830. Disponível em: http://www.planalto.gov.br/ccivil_03/LEIS/LIM/LIM-16-12-1830.htm. Acesso em 31/05/2019.

39 BRASIL. Código Penal de 1890. Disponível em: <http://www2.camara.leg.br/legin/fed/decret/18241899/decreto-847-11-outubro-1890-503086publicacaooriginal-1-pe.html>. Acesso em: 31/05/2019.

${ }^{40}$ Boticários eram os indivíduos que preparavam os medicamentos, eram os farmacêuticos.
} 
O cenário começa a se modificar a partir dos acontecimentos no contexto internacional com a Conferência Internacional do Ópio, que aconteceu em Haia, no ano de 1912, significando um divisor de águas no que diz respeito à legislação brasileira. No ano de 1915, o Brasil subscreveu o protocolo suplementar da Conferência, por meio do Decreto $\mathrm{n}^{\mathrm{o}} 11.841^{41}$, que mencionava "o abuso crescente do ópio, da morfina e seus derivados, bem como da cocaína". Segundo Nilo Batista, esse marco foi o início do "modelo sanitário" ${ }^{42}$.

Esse modelo foi caracterizado pelo emprego das técnicas higienistas ${ }^{43}$ através de instituições policiais, jurídicas e sanitárias. O viciado em substâncias entorpecentes era considerado como doente e se tornava objeto de internação compulsória com decisão judicial, embora não fosse criminalizado.

No ano de 1932, foi promulgado o decreto de $n^{\circ} 20.930$, motivado pelas Convenções “suplementares” de Genebra dos anos 1925, 1931 e 1936, que promoveu uma intervenção penal muito mais ampla e drástica, como podermos observar no seu artigo 25 :

"Art. 25. Vender, ministrar, dar, trocar, ceder, ou, de qualquer modo, proporcionar substâncias entorpecentes; propor-se a qualquer desses atos sem as formalidades prescritas no presente decreto; induzir, ou instigar, por atos ou por palavras, o uso de quaisquer dessas substâncias. (grifei)

Penas: De um a cinco anos de prisão celular e multa de 1:000\$0 a 5:000\$0”44.

Além dos verbos empregados no artigo 25, a posse ilícita também foi criminalizada no artigo 26 do mesmo Decreto, fenômeno que Zaffaroni

\footnotetext{
41 BRASIL. Decreto $\mathbf{n}^{\mathbf{0}} \mathbf{1 1 . 8 4 1}$, de 10 de fevereiro de 1915. Disponível em: <http://www2.camara.leg.br/legin/fed/decret/1910-1919/decreto-11481-10-fevereiro-1915574770-republicacao-98061pe.html>. Acesso em: 31/05/2019.

${ }^{42}$ BATISTA, Nilo. Política criminal com derramamento de sangue. Discursos sediciosos, v. 3, n. 5-6, p. 77-94, 1998.

${ }^{43}$ CHALHOUB, Sidney. Cidade febril: cortiços e epidemias na corte imperial. Editora Companhia das Letras, 2018.

44 BRASIL. Decreto $\mathbf{n}^{\mathbf{0}} \mathbf{2 0 . 3 9 0}$, de 11 de Janeiro de 1932, Disponível em: http://www.planalto.gov.br/ccivil_03/decreto/1930-1949/D20931.htm. Acesso em: 31/05/2019.
} 
nomeou como "multiplicação de verbos" $"$. Esse decreto, posteriormente aproveitado pelo Decreto de $\mathrm{n}^{\circ} 891$ do ano de 1938, conduziu a formulação do artigo 281 do famoso Código Penal de 1940.

Finalmente chegamos à legislação penal dos anos 1940, vigente até hoje $^{46}$. Em seu artigo 281, a matéria passou a proteger o bem jurídico da saúde pública. Os verbos criminalizados diminuíram, com o caput sob a rubrica: "Comércio, Posse ou Uso de Entorpecente ou Substância que determine Dependência Física ou Psíquica”. Com isso, o tráfico e o porte para o uso próprio foram equiparados, descriminalizando o consumo, apesar de que o legislador à época

retomou a técnica da norma penal em branco nas leis de drogas, o que denota a intenção de impor um controle mais rígido sobre o comércio de drogas ilícitas, por meio da utilização de fórmulas genéricas e termos imprecisos, ampliando seu significado ${ }^{47}$.

Isso nos mostra que a vontade do legislador é manter o usuário de drogas como doente, seguindo o modelo sanitário, ao passo que pretende criminalizar o comércio dessas drogas.

Com o golpe militar de 1964, introduzem-se as condições que dão origem ao "modelo bélico". É preciso ter em mente, que o contexto internacional era o da Guerra Fria, situação em que os países antagonistas (Estados Unidos e União Soviética) necessitavam manter relações internacionais militarizadas no âmbito da geopolítica, como também no nível interno dos países incorporados. A partir dessa noção, foi criado um instrumento teórico que reforçou a ideia de "inimigo interno": a doutrina da segurança nacional ${ }^{48}$.

\footnotetext{
${ }^{45}$ ZAFFARONI, Eugenio Raúl. La legislación anti-droga latinoamericana: Sus componentes de Derecho Penal Autoritario. Anuario No. 13-14 del Instituto de Ciencias Penales y Criminológicas de la Universidad Central de Venezuela, Caracas, 1995, p. 6

${ }^{46}$ Embora o código vigente, atualmente, seja o de 1940, é preciso observar que este sofreu grandes mudanças legislativas ao passar dos anos.

47 BOITEUX, Luciana. Drogas e cárcere: repressão às drogas, aumento da população penitenciária brasileira e alternativas. In: SHECAIRA, Sérgio Salomão (Org.). Drogas: uma nova perspectiva São Paulo: IBCCRIM, 2014.

${ }^{48}$ BATISTA, Nilo. Política criminal com derramamento de sangue. Discursos sediciosos, v. 3, n. 5-6, p. 77-94, 1998, p.85.
} 
Ao mesmo tempo, acontecia na década de 60, os movimentos de contracultura, protestos políticos e o momento em que a droga passa a ter uma atuação principal, com o aumento do consumo entre os jovens das classes altas e médias. Essa conjuntura foi de grande importância, pois nesse momento, não eram apenas os indivíduos marginalizados que estavam se drogando: o mal havia chegado às famílias tradicionais e aos cidadãos de bem. Passou-se a desenhar um problema moral, onde o distribuidor da droga, de origem humilde, que incitaria o consumo, seria qualificado como delinquente, enquanto o consumidor, corrompido pelos traficantes, qualificado como dependente, merecia tratamento médico.

Este cenário foi propício para os EUA colocar em prática as intervenções diplomático-militares, transferindo para os países marginais a responsabilidade pelo consumo interno. Esse discurso teve grande impacto nas políticas de segurança pública interna dos países da América Latina. Segundo Nilo Batista:

a produção jurídico-penal daquela conjuntura absorveu a idéia de que a generalização do contacto de jovens com drogas devia ser compreendida, no quadro da guerra fria, como uma estratégia do bloco comunista, para solapar as bases morais da civilização cristã ocidental, e que o enfrentamento da questão devia valer-se de métodos e dispositivos militares. A reunião do momento bélico e do elemento religioso-moral resulta na metáfora da guerra santa, da cruzada, que tem a vantagem - extremamente funcional para as agências policiais - de exprimir uma guerra sem restrições, sem padrões regulativos, na qual os fins justificam todos os meios ${ }^{49}$.

A partir da internalização e adoção do discurso norte americano, no Brasil passou viger diversas legislações que tinham a finalidade de controlar a questão das drogas, a partir da necessidade de combater a figura do inimigo interno. Então, com o decorrer desse processo de criminalização, é perceptível a diferenciação no tratamento do usuário e do traficante, dando origem a seletividade penal, cuja experiência é vivenciada até os dias de hoje.

Em 1968 houve uma importante alteração com o Decreto-lei no 385 que alterou a redação do art. 281 do Código Penal, equiparando a pena do

\footnotetext{
${ }^{49}$ BATISTA, Nilo. Política criminal com derramamento de sangue. Discursos sediciosos, v. 3, n. 5-6, p. 77-94, 1998 , p.87.
} 
usuário ao traficante. Dando grande passo para a completa descodificação da matéria, veio a Lei 5.276 de 29 de outubro de 1971, que manteve, contudo, o art. 281 do Código Penal e a equiparação entre usuário e traficante, aumentando a pena para 01 a 06 anos de reclusão. Além disso, constitui no seu artigo $1^{\circ}$, que era "dever de toda pessoa física ou jurídica colaborar no combate ao tráfico e uso de substâncias entorpecentes" ${ }^{\text {"50, }}$, se utilizando de uma estrutura normativa de imposição do dever jurídico para com a população.

Já em 1976, entra em vigor a Lei 6.368/76 ${ }^{51}$, que revogou o art. 281 do Código Penal de 1940, almejando a repressão do uso e comércio de substâncias ilícitas, tendo em vista que representariam um perigo presumido à saúde pública. Nesse sentido, o uso de drogas passou a ser reprimido com uma pena de 6 meses a 2 anos de detenção, enquanto a pena do tráfico ficou em 3 a 15 anos de prisão.

Em 1988, com a promulgação da tão esperada Constituição cidadã, que marca o início do período democrático no Brasil, o crime de tráfico de drogas é equiparado aos crimes hediondos. Em 90, foi editada a Lei 8.072/90, que acrescentou ao tráfico de drogas a proibição da progressão de regime, liberdade provisória e indulto ${ }^{52}$.

A última mudança significativa ocorreu no ano de 2006, com a promulgação da Lei de $\mathrm{n}^{\mathrm{o}}$ 11.343, a qual institui o Sistema Nacional de Políticas Públicas sobre Drogas - SISNAD, além de normatizar medidas de prevenção de uso indevido e definir os crimes relacionados às Drogas. Embora seja a legislação mais recente regulamentando a questão das drogas

\footnotetext{
50 BRASIL. Lei $\mathbf{n}^{\mathbf{5}} \mathbf{5 . 2 7 6}$ de 29 de outubro de 1971. Disponível em: https://www2.camara.leg.br/legin/fed/lei/1970-1979/lei-5726-29-outubro-1971-358075publicacaooriginal-1-pl.html. Acessado em: 01/06/2019.

51 BRASIL. Lei no $\mathbf{n}^{\mathbf{6} .368 / 76}$ de 21 de outubro de 1976. Disponível em: http://www.planalto.gov.br/ccivil_03/LEIS/L6368.htm. Acessado em: 01/06/2019.

52 Posteriormente, entendido como inconstitucional pelo STF no julgamento do Recurso Extraordinário com Agravo (ARE) 1052700. A inconstitucionalidade também é encontrada na Súmula Vinculante 26. Disponível em: http://www.stf.jus.br/portal/cms/verNoticiaDetalhe.asp?idConteudo=361875. Acessado em 31/05/2019.
} 
no Brasil, ainda reforça o discurso médico jurídico, aplicando modelos de descarcerização para o usuário e penas mais altas para as condutas identificadas como tráfico de drogas.

\section{2 - A vigente legislação e as consequências da aplicação dos artigos 33 e 28 da Lei de Drogas}

Como visto anteriormente, a atual regulamentação das drogas no Brasil, é exercida através da Lei 11.343 do ano de 2006. Podemos observar, pelo seu preâmbulo, que a Lei de Drogas:

institui o Sistema Nacional de Políticas Públicas sobre Drogas - SISNAD; prescreve medidas para prevenção do uso indevido, atenção e reinserção social de usuários e dependentes de drogas; estabelece normas para repressão à produção não autorizada e ao tráfico ilícito de drogas; define crimes e dá outras providências ${ }^{53}$.

A Lei pretende ir além da criminalização das condutas relacionadas às Drogas, instituindo políticas públicas e criando instituições para uma suposta proteção da sociedade. Nesse sentido, a criminalização das drogas é compreendida como um instrumento de proteção de um bem jurídico: a saúde pública, o que nos remete ao modelo sanitário vivido no início do século XX no Brasil.

Nota-se que a Lei de Drogas não define quais são as substâncias consideradas ilícitas, delegando tal função à Agência Nacional de Vigilância Sanitária (ANVISA), vinculada ao Ministério da Saúde. Esse fato permite que o Ministro da Saúde modifique, de forma discricionária, a abrangência da Lei, uma vez que se trata de norma penal em branco heterogenia ${ }^{54}$. Nesse sentido, Vera Malaguti cita Salo de Carvalho, afirmando que o autor

\footnotetext{
53 BRASIL. Lei $\mathbf{n}^{\mathbf{0}} \mathbf{1 1 . 3 4 3}$ de 23 de agosto de 2006. Disponível em: http://www.planalto.gov.br/ccivil_03/_ato2004-2006/2006/lei/111343.htm. Acessado em: 01/06/2019.

${ }^{54}$ A norma penal em branco heterogênea é uma norma complementada, em seu preceito primário, por norma diversa da fonte legislativa de onde emanou.
} 
Critica historicamente a legislação penal sobre a drogas no Brasil com dispositivos vagos e indeterminados e uso abusivo de normas penais em branco, que acabaram por legitimar sistemas de total violação das garantias individuais ${ }^{55}$.

Há grande divergência na doutrina quanto a possível violação do princípio da reserva legal ${ }^{56}$, tendo em vista que uma atribuição meramente legislativa, acaba se tornando matéria tratada pelo órgão do executivo.

Para o nosso objeto de estudo é importante destacar que essa definição do que é ou não substância ilícita, reflete na seletividade penal instrumentalizada pela Lei. Torna-se claro o objetivo da criminalização de determinadas drogas, enquanto outras - tão nocivas quanto (ou mais) - são naturalizadas pela rotina da população, o que será tratado melhor no próximo capítulo, situação em que abordaremos a principal função da criminalização pela Lei de Drogas.

Feita esta breve introdução, analisaremos as consequências na aplicação entre o que a Lei 11.343/06 chama de uso e tráfico de drogas. Embora ambas as condutas ainda sejam consideradas como crime, o procedimento pelo qual o sujeito envolvido é submetido, é completamente diferente.

O uso de drogas é tipificado pelo artigo 28 da Lei de Drogas, inserido no Título III "Das atividades de prevenção do uso indevido, atenção e reinserção social de usuários e dependentes de drogas". De acordo com o caput deste artigo, será considerado usuário e, com o parágrafo primeiro, correrá nas mesmas penas, quem:

Art. 28. Quem adquirir, guardar, tiver em depósito, transportar ou trouxer consigo, para consumo pessoal, drogas sem autorização ou em desacordo com determinação legal ou regulamentar será submetido às seguintes penas:

I - Advertência sobre os efeitos das drogas;

II - Prestação de serviços à comunidade;

\footnotetext{
${ }^{55}$ BATISTA, Vera Malaguti. Difíceis ganhos fáceis: drogas e juventude pobre no Rio de Janeiro. Rio de Janeiro, Instituto Carioca de Criminologia, 2003, p. 83.

${ }^{56} \mathrm{O}$ Princípio da Reserva Legal determina que só será considerada como Infração penal a conduta prevista como tal na Lei. Esse princípio está abarcado pela Constituição Federal em seu artigo $5^{\circ}$, inciso II.
} 
III - Medida educativa de comparecimento a programa ou curso educativo.

§10 Às mesmas medidas submete-se quem, para seu consumo pessoal, semeia, cultiva ou colhe plantas destinadas à preparação de pequena quantidade de substância ou produto capaz de causar dependência física ou psíquica. $(\text { sublinhei })^{57}$.

Observa-se a partir dos incisos deste artigo, que o usuário não está submetido às penas de privação de liberdade, mas sim às penas chamadas alternativas, quais sejam a advertência, a prestação de serviços à comunidade e a medida educativa. Com isso, o usuário enfrentará o rito dos Juizados Especiais Criminais (JECRIM) ${ }^{58}$, tendo em vista que é considerado crime de menor potencial ofensivo.

No que tange à possibilidade de uma prisão cautelar, a Lei 11.343 é clara, no seu artigo 48, que o usuário não poderá ser submetido à prisão em flagrante, "devendo o autor do fato ser imediatamente encaminhado ao juízo competente ou, na falta deste, assumir o compromisso de a ele comparecer, lavrando-se termo circunstanciado", segundo o texto do artigo.

Quando o sujeito for pego usando a droga, ele deverá ser imediatamente encaminhado ao juízo competente, que nesse caso é o JECRIM, para assinar um termo circunstanciado, só podendo ser preso em flagrante caso se recuse a compararecer, de acordo com o artigo 69 da Lei 9.099/95, do Juizado Criminal. No caso, também não cabe a prisão preventiva, prevista no artigo 311 do Código de Processo Penal, pois não satisfaz os requisitos necessários previstos no artigo 313 do mesmo Código.

Isso mostra que, apesar do uso de drogas ainda ser criminalizado, as consequências, quando comparado aos demais crimes, são mais brandas, não admitindo a prisão em flagrante ou a preventiva e nenhum tipo de pena de

\footnotetext{
57 BRASIL. Lei $\mathbf{n}^{\mathbf{0}} \mathbf{1 1 . 3 4 3}$ de 23 de agosto de 2006. Disponível em: http://www.planalto.gov.br/ccivil_03/_ato2004-2006/2006/lei/111343.htm. Acessado em: 01/06/2019.

58 BRASIL. Lei $\mathbf{n}^{\mathbf{0}} \mathbf{9 . 0 9 9}$ de 26 de setembro de 1995. Disponível em: http://www.planalto.gov.br/ccivil_03/leis/19099.htm. Acessado em: 01/06/2019.
} 
privação de liberdade. Na grande maioria das vezes, o Ministério Público oferece o benefício da Transação Penal ${ }^{59}$, e se o acusado aceita, o processo é arquivado, "limpando" o nome do indivíduo.

Diferente ocorre com o acusado pelo artigo 33 da Lei de Drogas. O Crime de tráfico de drogas se encontra em um capítulo diferente, dentro da mesma Lei, qual seja "Capítulo II: Dos crimes”. Cumpre ressaltar que o artigo 33, é um tipo misto alternativo, pois abarca diversos núcleos que atingem o mesmo bem jurídico, como in verbis:

Art. 33. Importar, exportar, remeter, preparar, produzir, fabricar, adquirir, vender, expor à venda, oferecer, ter em depósito, transportar, trazer consigo, guardar, prescrever, ministrar, entregar a consumo ou fornecer drogas, ainda que gratuitamente, sem autorização ou em desacordo com determinação legal ou regulamentar:

Pena - reclusão de 5 (cinco) a 15 (quinze) anos e pagamento de 500 (quinhentos) a 1.500 (mil e quinhentos) dias-multa. (sublinhei)

Somente no caput do artigo, é possível contarmos dezoito verbos que criminalizam a conduta de traficar drogas. Mas não é só. O parágrafo primeiro do mesmo artigo, prevê igual pena:

$\S 1^{\circ}$ Nas mesmas penas incorre quem:

I - importa, exporta, remete, produz, fabrica, adquire, vende, expõe à venda, oferece, fornece, tem em depósito, transporta, traz consigo ou guarda, ainda que gratuitamente, sem autorização ou em desacordo com determinação legal ou regulamentar, matéria-prima, insumo ou produto químico destinado à preparação de drogas;

II - semeia, cultiva ou faz a colheita, sem autorização ou em desacordo com determinação legal ou regulamentar, de plantas que se constituam em matériaprima para a preparação de drogas;

III - utiliza local ou bem de qualquer natureza de que tem a propriedade, posse, administração, guarda ou vigilância, ou consente que outrem dele se utilize, ainda que gratuitamente, sem autorização ou em desacordo com determinação legal ou regulamentar, para o tráfico ilícito de drogas. (sublinhei)

Percebe-se que o tráfico de drogas é um crime demasiadamente abrangente no Brasil. Desde o indivíduo que produz a matéria prima, passando por aquele que embala a droga, até o que, de fato, a vende, é

\footnotetext{
${ }^{59}$ A transação penal é um instituto despenalizador pré-processual inserido pela Lei 9.099/95, em seu artigo 76 , que se baseia no direito penal consensual.
} 
tipificado como traficante e incorre na pena mínima de 05 anos e máxima de $15 \operatorname{anos}^{60}$. Sobre isso, trata Orlando Zaccone:

A conduta de quem dispara fogos de artifício para avisar da chegada da polícia recebe o mesmo tratamento penal de quem tem o comando do negócio no varejo, bem como dos grandes produtores e daqueles respeitáveis empresários que financiam a produção e o comércio destas substâncias com todos respondendo, em abstrato, pelo mesmo crime. ${ }^{61}$

As consequências para o crime de tráfico também se tornam distantes daquelas que os usuários vivenciam. Há a possibilidade de prisão em flagrante, segundo os artigos 301 e seguintes do Código de Processo Penal, combinado com o artigo 50 da Lei de Drogas. Como consta na própria Lei, a autoridade policial terá 30 dias ou 90 dias para concluir o inquérito, dependendo se o indiciado estiver preso ou solto.

O crime de tráfico de Drogas não faz jus à suspensão condicional do processo, previsto no artigo 89 da Lei $9.099 / 95^{62}$, bem como não faz jus à suspensão condicional da pena, prevista no artigo 78 do Código Penal, tendo em vista que a pena mínima do crime de tráfico é maior do que prevê o texto de ambos os benefícios citados acima.

Da mesma forma, não é cabível a substituição da pena privativa de liberdade para a pena restritiva de direito, isso porque, de acordo com o artigo 44 do Código Penal, para haver tal substituição, a pena privativa de liberdade precisa ser igual ou inferior a 04 anos, o que não ocorre na situação descrita, considerando que a pena mínima para o tráfico é de 05 anos, como visto anteriormente.

Com isso, percebemos que a real intenção do legislador, quando aumentou a pena mínima do tráfico de drogas ${ }^{63}$, para 05 anos, foi retirar qualquer direito aos benefícios da suspensão condicional do processo ou da

\footnotetext{
${ }^{60}$ Esse é o preceito primário para a análise inicial da aplicação da pena, que poderá ser modificada com as agravantes e atenuantes e causa de aumento e diminuição da pena.

${ }^{61}$ ZACCONE, Orlando. Acionistas do nada: quem são os traficantes de drogas. Rio de Janeiro: Revan, v. 2, 2007, p. 12.

62 BRASIL. Lei $\mathbf{n}^{\mathbf{0}} \mathbf{9 . 0 9 9}$ de 26 de setembro de 1995 . Disponível em: http://www.planalto.gov.br/ccivil_03/leis/19099.htm. Acessado em: 01/06/2019.

${ }^{63} \mathrm{Na}$ legislação anterior, do ano de 1976, a pena para o usuário era de 03 anos.
} 
pena e impedir a substituição da pena privativa de liberdade pela restritiva de direitos. Essa mudança implicou, junto a diversos outros fatores, em um aumento exponencial de encarcerados por tráfico de drogas.

Outro fato que merece destaque é que a partir do disposto no artigo $2^{\circ}$, em seu parágrafo $2^{\circ}$ da Lei 8.072 de $1990^{64}$, o crime de tráfico de drogas passou a ser considerado equiparado aos crimes hediondos. Esta previsão faz com que o crime do artigo 33 da Lei de Drogas seja insuscetível de pagamento de fiança, bem como impossibilita a determinação de anistia, graça e indulto, medidas que extinguem a punibilidade, conforme o artigo 107 do Código Penal ${ }^{65}$.

Ademais, os crimes hediondos ou equiparados, estão submetidos à um procedimento diferenciado quanto a progressão de regime. Em regra, para o apenado ou apenada progredir de regime, além de preencher os requisitos subjetivos previstos pela Lei de Execução Penal, tem que observar a fração de 1/6 da pena. Porém, para os crimes previstos pela Lei 8.072/90, a fração observada para a progressão é de $2 / 5$ da pena, ou até mesmo $3 / 5$ da pena, em caso de reincidência.

Quando a Lei de crimes hediondos foi promulgada, ainda previa a obrigatoriedade de o apenado pelo crime de tráfico de drogas cumprir a pena em regime inicialmente fechado. No entanto, de acordo com o plenário do STF, esse item foi declarado inconstitucional, de forma incidental, no julgamento do Habeas Corpus (HC) $111.840 .{ }^{66}$

Com o exposto, podemos perceber como o tráfico de drogas se tornou um dos crimes mais graves previstos pela legislação brasileira. Na direção

\footnotetext{
64 BRASIL. Lei $\mathbf{n}^{\mathbf{0}} \mathbf{8 . 0 7 2}$ de 25 de Julho de 1990. Disponível em: http://www.planalto.gov.br/ccivil_03/Leis/L8072.htm. Acessado em: 01/06/2019.

65 BRASIL. Decreto-Lei No 2.848, De 7 De Dezembro De 1940. Disponível em: http://www.planalto.gov.br/ccivil_03/decreto-lei/del2848compilado.htm. Acessado em:01/06/2019.

${ }^{66}$ STF, Habeas-corpus no 111.840, Rel. Ministro Dias Toffoli, Brasília, DF, 2012. Didisponível em:http://stf.jus.br/portal/jurisprudencia/listarJurisprudencia.asp?s 1=\%28\%28HABEAS+CORPU $\mathrm{S}+\% 28 \mathrm{HC} \% 29+111840 \% 29 \% 29+\mathrm{E}+\mathrm{S} \% 2 \mathrm{EPRES} \% 2 \mathrm{E} \&$ base=basePresidencia\&url=http://tinyurl.c om/yyuspwyk. Acessado em:01/06/2019.
} 
oposta, temos o crime previsto para o usuário, que anteriormente era penalizado com prisão e atualmente só abarca penas alternativas pela Lei de 2006.

\section{3 - A aplicação subjetiva do artigo 33 da Lei de Drogas}

Uma vez demonstrada as diferentes consequências das acusações e, consequentemente, condenações entre os artigos 28 e 33 da Lei de Drogas, nos resta analisar quais os critérios que a própria Lei 11.343/06 traz para a aplicação desses artigos.

A partir desse estudo, restará claro que os critérios de aplicação do artigo que separam o uso do tráfico, são absolutamente abstratos, considerando que o legislador conferiu às decisões dos magistrados, discricionariedade ao distinguir o título de traficante ou de usuário do acusado.

É necessário destacar que há um estereótipo pré-constituído de quem figuraria como traficante e, consequentemente, como usuário. Fazer essa distinção é importante, pois se revelará claro o motivo pelo qual a decisão do juiz, embora subjetiva, já tem um caminho trilhado. De imediato, os critérios abordados pela Lei parecem razoáveis e suficientes para oferecer um trajeto justo na atribuição do título de traficante e usuário ao agente, mas ao analisarmos a fundo, verificamos que não é isso que acontece.

Nota-se que embora a decisão pela aplicação dos artigos, seja subjetiva, isto é, corresponda à analise pessoal e íntima do magistrado, o preconceito, os estereótipos e os estigmas, desempenham uma função determinante no destino já marcado dos sujeitos que estão inseridos na questão das drogas através do surgimento de uma manifestação moral e política. 
Com um discurso do medo fortalecido pela mídia, onde a imagem do traficante é associada à de um ser violento e cruel, atribuindo à guerra às drogas uma função de exterminar a violência, se forma a figura do traficante como inimigo da população. Baratta afirma que no Brasil, o inimigo não é externo, como acontece com a maioria dos países da América do Sul, mas sim interno. Nós construímos nosso próprio inimigo para ter um argumento que justifique o genocídio à população pobre, negra e favelada.

A guerra contra a droga no Brasil não é uma guerra internacional comandada pelos Estados Unidos e por outros países centrais; não é uma guerra contra um inimigo externo; é uma guerra contra o inimigo interno; um assunto, como se viu acima, de segurança nacional e urbana ${ }^{67}$.

Desse modo, o traficante surge com o estereótipo orientado pela classe mais vulnerável, que não tem forças para lutar de frente com o poder punitivo do Estado que legitima a violência contra essa parte da população. Para entender como funciona o processo que seleciona quem serão os indivíduos marcados pelos crimes, precisamos compreender como é pensado o processo de criminalização.

A escolha do legislador por tornar subjetiva a decisão do magistrado que determinará se o indivíduo é usuário ou traficante não foi por acaso. Esse cenário traduz o que Nilo Batista e Zaffaroni chamaram em sua lição, brilhantemente, de criminalização primária ${ }^{68}$. Para os autores, o poder punitivo perpassa um processo seletivo de criminalização que se desenvolve em duas etapas: a criminalização primária e a criminalização secundária.

Criminalização primária é o ato e o efeito de sancionar uma lei penal material que incrimina ou permite a punição de certas pessoas. Trata-se de um ato formal fundamentalmente programático: o deve ser apenado é um programa que deve ser cumprido por agencias diferentes daquelas que o formulam. Em geral, são as agências políticas (parlamentos, executivos) que exercem a criminalização primária, ao passo que o programa por elas estabelecido deve ser realizado pelas agências de criminalização secundária (policiais, promotores, advogados, juízes, agentes penitenciários). Enquanto a criminalização primária (elaboração de leis

\footnotetext{
${ }^{67}$ BARATTA, Alessandro. Prefácio. In: BATISTA, Vera Malaguti. Difíceis ganhos fáceis: drogas e juventude pobre no Rio de Janeiro. Rio de Janeiro, Instituto Carioca de Criminologia, 2003, p.23.

${ }^{68}$ BATISTA, Nilo et al. Direito Penal Brasileiro: primeiro volume: Teoria Geral do Direito Penal. Rio de Janeiro, RJ: Revan, 2003, p. 43.
} 
penais) é uma declaração que, em geral, se refere a condutas e atos, a criminalização secundária é a ação punitiva exercida sobre pessoas concretas $(\ldots)^{69}$.

Então, quando o legislador elabora a lei, atribuindo critérios para diferenciar o usuário do traficante, se insere nessa lógica de criminalização primária. E esse fato se torna importante ao considerar que as agências ${ }^{70}$ de criminalizações secundárias aplicarão, consequentemente, de modo seletivo, o que foi estabelecido em Lei.

Para os autores, apesar da criminalização primária implicar em uma certa seletividade, é a criminalização secundária que concretiza e perpetua essa seleção. Isso porque, ao fazer as normas, o legislador permanece em certo nível de abstração, enquanto as agências secundárias estão incumbidas de decidir quem são as pessoas que passarão pelo sistema punitivo. Orlando Zaconne, quando aborda o assunto da criminalização, com base na lição de Nilo Batista e Zaffaroni, afirma que

a seleção punitiva ocorre uma vez que é impossível para os gestores da criminalização secundária realizarem o projeto "faraônico" de criminalização primária previsto em todas as leis penais de um país. Ou seja, não é possível ao sistema penal prender, processar e julgar todas as pessoas que realizam as condutas descritas em Lei como crime, e por seguinte, as agências penais devem optar entre o caminho da inatividade ou da seleçãa ${ }^{71}$.

Quando analisamos o nosso Código Penal e as legislações extravagantes que tipificam material e formalmente as condutas, admitindo a ideia de uma lesividade a um bem jurídico que deve ser tutelado, percebemos que o direito penal chega cada vez mais perto de ocupar todas as áreas vividas pelo ser humano. Desse modo, todos habitantes do Brasil, ou pelo menos a grande maioria, já praticaram ou ainda irão praticar algum desses crimes previstos nas legislações.

\footnotetext{
${ }^{69}$ BATISTA, Nilo et al. Direito Penal Brasileiro: primeiro volume: Teoria Geral do Direito Penal. Rio de Janeiro, RJ: Revan, 2003, p. 43.

${ }^{70}$ Segundo Nilo Batista e Raúl Zaffaroni, na obra "Direito Penal Brasileiro - Volume I", agências seria uma referência aos entes gestores da criminalização.

${ }^{71}$ ZACCONE, Orlando. Acionistas do nada: quem são os traficantes de drogas. Rio de Janeiro: Revan, v. 2, 2007, p. 16
} 
Quando Zaccone se utiliza do termo "faraônico" é justamente para demonstrar que cada vez mais as agências de criminalização primária, transformam condutas em crimes, muitas vezes até pelo clamor do senso comum. Ocorre que, como bem citado na passagem acima, não é possível que todos os indivíduos sejam criminalizados, seja porque as agências secundárias não seriam capazes de realizar essa função, ou até mesmo porque a sociedade deixaria de ser funcional, uma vez que todos estariam atrás das grades ou cumprindo algum tipo de pena.

É por esse motivo que as agências secundárias de criminalização, principalmente, devem escolher, ou melhor, selecionar quem serão os corpos criminalizados. Vale destacar que a mídia também exerce uma função muito importante nessa seleção, quando divulgam os ocorridos dessa parte da população que fora escolhida para sofrer as consequências do cárcere e do sistema penal, como se estes fossem os únicos delitos cometidos na vida em sociedade. É nesse sentido que Nilo Batista e Zaffaroni anunciam que

\begin{abstract}
A inevitável seletividade operacional da criminalização secundária e sua preferente orientação burocrática (sobre pessoas sem poder e por fatos grosseiros e até insignificantes) provocam uma distribuição seletiva em forma de epidemia, que atinge apenas aqueles que têm baixas defesas perante o poder punitivo, aqueles que se tornam vulneráveis à criminalização secundária porque: a)suas características pessoais se enquadram nos estereótipos criminais; b) sua educação só lhes permite realizar ações ilícitas toscas e, por conseguinte, de fácil deteç̧ão; c) porque a etiquetagem suscita a assunção do papel correspondente ao estereótipo, com o qual seu comportamento acaba correspondendo ao mesmo. ${ }^{72}$
\end{abstract}

Encontramos a materialização da criminalização desse estereótipo na aplicação da Lei de Drogas, que oferece de bandeja ao juiz a possibilidade de uma decisão motivada por preconceitos. Destaca-se que esses critérios que pautam a escolha do juiz pela aplicação do tráfico ou do uso, está inserido no próprio artigo de uso de drogas. É através do parágrafo $2^{\circ}$ do artigo 28 , que o juiz encontra seu roteiro rumo à condenação do traficante:

$\S$ 2o Para determinar se a droga destinava-se a consumo pessoal, o juiz atenderá à natureza e à quantidade da substância apreendida, ao local e às condições em

\footnotetext{
72 BATISTA, Nilo et al. Direito Penal Brasileiro: primeiro volume: Teoria Geral do Direito Penal. Rio de Janeiro, RJ: Revan, 2003, p. 47.
} 
que se desenvolveu a ação, às circunstâncias sociais e pessoais, bem como à conduta e aos antecedentes do agente ${ }^{73}$. (grifei)

Quando lemos esse parágrafo, percebemos que embora a escola positivista seja considerada antiquada e ultrapassada, na visão da nova criminologia, ainda sentimos os rastros que o legado de Lombroso deixou. Isso porque, o parágrafo citado, pretende determinar quem é traficante e quem é usuário, a partir da análise subjetiva das condições em que cada indivíduo estava submetido, remetendo-nos ao método experimental e de observação, que nos afasta do objeto estudado.

Para que não ocorram obscuridades nas decisões, em teoria, todos os critérios legais colocados no artigo $28, \S 2^{\circ}$ da Lei 11.343/06 deveriam ser mencionados de forma fundamentada na decisão judicial, considerando que o princípio da presunção da inocência, previsto no artigo $5^{\circ}$, inciso $\mathrm{LVII}^{74}$ impõe valoração benéfica ao perseguido penal para as situações em que não haja elementos de informação nos autos, mas na prática estamos diante de decisões arbitrárias e obscuras.

Analisaremos como esse caminho perverso rumo à determinação da destinação dos entorpecentes, é uma ferramenta sem igual para a seletividade na criminalização das drogas. O objetivo aqui, é dividir esse parágrafo em três pilares, sendo o primeiro relativo à natureza e quantidade; o segundo ao local e às condições em que se desenvolveu a ação, às circunstâncias sociais e pessoais; e em terceiro à conduta e aos antecedentes do agente, para que possamos analisar em que medida esses três critérios influenciam nesta seletividade.

Primeiramente, cumpre questionar qual é a relevância da natureza da droga como um critério que separa o uso do tráfico. Por natureza, entende-se que a Lei de Drogas se refere ao tipo de droga que foi encontrada, e se de

\footnotetext{
73 BRASIL. Lei $\mathbf{n}^{\mathbf{0}} \mathbf{1 1 . 3 4 3}$ de 23 de agosto de 2006. Disponível em: http://www.planalto.gov.br/ccivil_03/_ato2004-2006/2006/lei/111343.htm. Acessado em: 10/06/2019.

74 BRASIL. Constituição da República Federativa do Brasil de 1988. Disponível em: http://www.planalto.gov.br/ccivil_03/constituicao/constituicao.htm. Acessado em:10/06/2019.
} 
acordo com o regulamento da ANVISA, essa droga é considerada entorpecente ou não. Porém, o critério da natureza deve ser conjugado junto ao da quantidade. Ou seja, a partir da natureza da droga e da quantidade dessa droga que está sob o domínio do indivíduo, ele poderá ser figurado como usuário ou traficante.

O problema é que a Lei de Drogas não definiu exatamente qual seria a quantidade limite para afastar o uso do tráfico, colocando nas mãos dos próprios julgadores o ônus de resolver esse quebra-cabeça.

De acordo com o Superior Tribunal de Justiça (STJ), no julgamento do Habeas Corpus $160.320^{75}$, que teve decisão unânime, na relatoria da ministra Laurita Vaz, não cabe aos legisladores determinar qual quantidade de droga é considerada relevante no processo, trazendo essa responsabilidade para o poder judiciário.

O fato de não haver uma quantidade objetiva descrita em Lei, traz muita insegurança em relação à qual será o destino do indivíduo que foi pego com as drogas. Além disso, abre caminho para um discurso seletivo, que tende a estigmatizar uma parte da população como traficante. Nesse sentido, compreende Roberta Pedrinha:

A lei silencia quanto à quantidade específica de droga para classificar o usuário e o traficante, ficando a seleção ao arbítrio dos representantes do Estado. Dessa forma, a condição social, a cor, a raça de certos indivíduos serão fatores determinantes na aptidão à captura seletiva da polícia e dos magistrados. ${ }^{76}$

A partir do olhar seletivo, o adolescente de classe média/alta, branco, morador da Zona Sul ou da Barra da Tijuca da capital do Rio de Janeiro, que for pego com quantidade significativa de droga, provavelmente não sofrerá as mesmas consequências em comparação a um jovem de classe mais baixa,

\footnotetext{
${ }^{75}$ STJ. Habeas-corpus no 160.320. Rel. Ministra Laurita Vaz, Brasília, DF, 2011. Disponível em: https://ww2.stj.jus.br/processo/revista/documento/mediado/?componente=ATC\&sequencial=1734 5216\&num_registro $=201000123340 \&$ data $=20110922 \&$ tipo $=5 \&$ formato $=P D F$. Acessado em: $10 / 06 / 2019$

${ }^{76}$ PEDRINHA, Roberta Duboc. Notas sobre a política criminal de drogas no Brasil: Elementos para uma reflexão crítica. Fls. 5486. Disponível em: http://www.publicadireito.com.br/conpedi/manaus/arquivos/anais/salvador/roberta_duboc_pedrinh a.pdf. Acessado em: 08/06/2019.
} 
negro, morador da favela do mesmo município, com a mesma quantidade de drogas. O vazio dessa norma, ao passo que beneficia o indivíduo considerado como usuário, quando é abordado com grandes quantidades de substâncias ilícitas, deixa marcas no individuo estigmatizado, mesmo quando é abordado com pequenas quantidades dessas mesmas substâncias.

Em uma passagem da obra "Acionistas do nada: quem são os traficantes de drogas"77, de Orlando Zaccone, que atualmente é delegado da Polícia Civil do Rio de Janeiro, é narrado um episódio em que um delegado de seu concurso, lotado na $14^{\mathrm{a}}$ DP do Leblon, autuou, em flagrante, dois jovens residentes da zona sul do Rio de Janeiro, pela conduta de usuários, por estarem transportando, em um veículo importado, 280 (duzentos e oitenta) gramas de maconha. Quando acaba de narrar o ocorrido, se pergunta:

será que a mesma postura seria por ele adotada se os jovens fossem negros e estivessem transportando a droga para uso próprio em um ônibus, ainda que comprovassem trabalho e tivessem a ficha sem anotação? ${ }^{78}$.

A partir dessa passagem, podemos concluir que a análise da quantidade de drogas é feita não de forma isolada, mas levando em consideração os demais aspectos que analisaremos em diante.

Nesse sentido, passamos a verificar o que o legislador esperava quando adicionou à análise subjetiva do artigo de drogas, o critério do local, as condições em que se desenvolveu a ação, e as circunstâncias sociais e pessoais do acusado.

Para tratarmos do local como um dos aspectos a serem considerados na diferenciação do uso e do tráfico de drogas, precisamos observar inicialmente, que no Rio de Janeiro há uma divisão clara de territórios que se relaciona diretamente com o poder aquisitivo dos moradores.

\footnotetext{
78 ZACCONE, Orlando. Acionistas do nada: quem são os traficantes de drogas. Rio de Janeiro: Revan, v. 2, 2007, p.19.
} 
Como visto anteriormente, temos a Zona Sul e a Barra da Tijuca, zona e bairro da capital, respectivamente, onde vive a classe com o maior poder aquisitivo, de um modo geral ${ }^{79}$. De outro lado, temos as áreas mais periféricas do ponto de vista econômico, como Bangu, Santa Cruz e Jacarepaguá. Essa distinção se torna essencial uma vez que o local onde o indivíduo mora, se torna argumento para defini-lo como usuário ou traficante.

Zaccone, quando trata do assunto, apresenta o número de flagrantes pelo delito de tráfico ocorrido na Delegacia de Polícia, traçando uma diferença entre os Bairros da Zona Sul e os demais bairros periféricos, extraídos pelo Instituto de Segurança Pública (ISP). De acordo com os números levantados pelo mapa de ocorrência por detalhamento de delito de tráfico de entorpecente de 2005, as delegacias de Bangu, Santa Cruz, Bonsucesso, Jacarepaguá, Imabariê e São Cristóvão, somariam 561 flagrantes por tráfico de drogas, onde só em Bangu, contabilizam 186 flagrantes do total. Ao passo que Gávea, Botafogo, Copacabana, Leblon, Ipanema e Barra de Tijuca, somariam somente 63 flagrantes pelo mesmo delito.

A partir desses números, podemos extrair dois fatos. $\mathrm{O}$ primeiro é que dois bairros da mesma Zona Oeste apresentam os números mais extremos: a $16^{\mathrm{a}}$ DP da Barra da Tijuca que obteve somente 03 flagrantes de tráfico, enquanto a $34^{\mathrm{a}} \mathrm{DP}$ de Bangu obteve 186 flagrantes. O segundo é que todos esses bairros da Zona Sul do Rio de Janeiro, somados à Barra da Tijuca, contabilizariam no total, quase $1 / 3^{80}$ das apreensões que somente a delegacia do bairro de Bangu apresentou.

Essa disparidade mostra-nos que a grande parte dos traficantes estão em Bangu e nos demais bairros que não se localizam na zona sul ou então,

\footnotetext{
${ }^{79}$ Isso porque na Zona Sul, ainda encontramos alguns favelas como a Rocinha, o Vidigal e o Cantagalo.

${ }^{80}$ Significa dizer que de 186 flagrantes ocorridos no Bairro de Bangu, um terço seriam 62 flagrantes, ou seja, quase o mesmo número de todos os flagrantes ocorridos nos bairros da Zona Sul e Barra da Tijuca.
} 
que existe uma seletividade quanto ao território que se encontra o traficante. Nas palavras de Zaccone:

Diante dos fatos, se um pesquisador tivesse acesso às estatísticas policiais no Rio de Janeiro, chegaria à conclusão de que não existe tráfico de drogas ilícitas na Barra da Tijuca. O sistema penal realiza, assim, um duplo processo seletivo presente não só na questão das drogas, bem como na persecução de todos os demais comportamentos delitivos ${ }^{81}$.

É preciso olharmos para além do que os números nos mostram se quisermos entender a realidade que se passa no Rio de Janeiro. Esse caso é um típico exemplo do que já tratamos sobre agências de criminalização secundária e seletividade punitiva. Os apartamentos da Zona Sul e os condomínios da Barra da Tijuca não são alvos de operações policiais cotidianas que desrespeitam o Estado Democrático de Direito.

Nesses locais, por exemplo, há a necessidade da autoridade policial de cumprir a regra do mandado de busca e apreensão a partir de uma autorização judicial, prevista no artigo 241 do Código de Processo Penal ${ }^{82}$. O mesmo ocorre com a busca pessoal, que quando não há mandado judicial, é necessária pelo menos uma fundada suspeita, como apregoa Cleunice A. Valentim Bastos Pitombo:

em regra, deve ocorrer com mandado judicial. O Código de Processo Penal, entretanto, permite sua realização sem autorização judicial (art. 244 do CPP). Mas sempre com observância da garantia constitucional do respeito à integridade física e moral do indivíduo. ${ }^{83}$

Diferentemente do que ocorre nesses espaços privilegiados, os moradores das comunidades e locais mais pobres sofrem diariamente com o abuso de autoridade policial e transgressão de seus direitos individuais à privacidade e liberdade. Não há necessidade de mandado judicial para busca

\footnotetext{
${ }^{81}$ ZACCONE, Orlando. Acionistas do nada: quem são os traficantes de drogas. Rio de Janeiro: Revan, v. 2, 2007, p. 13.

82 Brasil. Decreto Lei $\mathbf{n}^{\mathbf{0}} \mathbf{3 . 6 8 9}$ de 03 de outubro de 1941. Disponível em: http://www.planalto.gov.br/ccivil_03/decreto-lei/del3689.htm. Acessao em: 10/06/2019

${ }^{83}$ PITOMBO, Cleunice A. Valentim Bastos. Da busca e da apreensão no processo penal. São Paulo: Editora Revista dos Tribunais, 1999. p. 133.
} 
e apreensão e, muito menos, haver fundada suspeita para justificar a busca pessoal. Conforme lição de Zaccone:

O espaço em que se opera a venda de drogas ilícitas na zona sul e Barra da Tijuca é completamente distinto de outras regiões, como Jacarepaguá, Bangu e Bonsucesso. Os grandes pontos de venda de drogas ilícitas na Barra, por exemplo, se localizam em áreas residenciais, de acesso privado, como apartamentos e condomínios, espaços onde a polícia não tem entrada franqueada. Imagine a proposta de se policiar ostensivamente as entradas e saídas dos grandes condomínios da Avenida das Américas para "combate" ao tráfico de drogas! ${ }^{84}$

Essa realidade se torna importante na medida em que os flagrantes são contabilizados a partir do momento em que há ação policial exercendo a criminalização secundária. Se essa ação chega a alguns lugares prédeterminados, e não chega a outros, os dados referentes às consequências dessas investidas, se tornam fictos, mostrando-nos que "em se tratando de segurança pública, não são os índices que determinam a polícia, mas a polícia que determina os índices" $" 85$.

Além das estatísticas, que não mostram verdadeiramente quem são os traficantes e os usuários de drogas, para a construção do estereótipo e do preconceito acerca dos moradores de áreas mais pobres, a mídia hegemônica exerce um influente papel. Através das matérias sensacionalistas, das reportagens tendenciosas e da necessidade de mostrar as operações nas favelas e nas comunidades em todas as oportunidades que aparecem, vai se construindo uma relação direta entre o tráfico e esses lugares. Um bom exemplo é o filme Tropa de Elite, que ficou mundialmente conhecido pelas operações do $\mathrm{BOPE}^{86}$, no comando do Capitão Nascimento, favelas à dentro.

Nessa linha, entende Maria Lucia Karam:

As distribuições desiguais do status de criminoso determina a ideia de criminalidade como um comportamento característico de indivíduos provenientes daquelas camadas mais baixas e marginalizadas, levando à identificação das classes subalternas como classes perigosas. No caso das drogas, pense-se, por

\footnotetext{
${ }^{84}$ ZACCONE, Orlando. Acionistas do nada: quem são os traficantes de drogas. Rio de Janeiro: Revan, v. 2, 2007, p. 18.

${ }^{85}$ ZACCONE, Orlando. Acionistas do nada: quem são os traficantes de drogas. Rio de Janeiro: Revan, v. 2, 2007, p. 17.

${ }^{86}$ Sigla para Batalhão de Operações Policiais Especiais.
} 
exemplo, nas favelas do Rio de Janeiro, em relação às quais se passa a ideia de uma ligação generalizada de seus moradores com o tráfico, reproduzindo-se a mesma linha que, intencionalmente, cria o já mencionado estereótipo delitivo latino americano. Nesse caso de países perigosos, basta lembrar que, quando se fala de drogas, não se pensa, por exemplo, na Suíça, levando mais branco, mas apenas na Colômbia com seus cartéis, ou na Bolívia, com suas folhas de coca ${ }^{87}$.

O local, como um dos critérios que determinam a aplicação do tipo de tráfico ou de uso de drogas, conforme prega o parágrafo segundo do artigo 28 da Lei 11.343 , se torna um instrumento para seletividade na medida em que se estigmatiza o morador das favelas e periferias como traficantes, enquanto os moradores do "asfalto" são conhecidos como usuários. A partir desse determinismo, a análise do juiz deixa de ser parcial, seja pelos números que mostram uma realidade ficta, seja pela mídia que transforma as favelas em verdadeiros habitats de bandido e traficante ou até mesmo pela política dos governantes em travar uma guerra contra às drogas tendo as periferias e favelas como o cenário de fundo.

Após essa breve investigação sobre o critério do local, passamos a analisar em diante, o que o legislador quis dizer com circunstâncias sociais e pessoais do agente. Esse é o critério que melhor demonstra o caráter de seletividade que contém a aplicação subjetiva do juiz a partir do parágrafo segundo do artigo 28. É a partir desse momento que as condições financeiras, o modo de se vestir, o fato do agente ser empregado ou desempregado, se parece ter má ou boa índole, faz-se relevante.

A condição financeira se torna protagonista para definir qual o tipo penal em que o agente será inserido. Todos esses critérios analisados acima, só fazem sentido quando entendemos que a guerra às drogas, na verdade, é uma guerra aos pobres. Como estudamos nos capítulos anteriores, não é de hoje que a classe dominante pretende exercer um controle das classes dominadas, em razão da manutenção da hegemonia do sistema capitalista,

\footnotetext{
${ }^{87}$ KARAM, Maria Lúcia. A esquerda punitiva. Discursos sediciosos, v. 1, n. 1, 1996, p. 60.
} 
como anuncia Vera Malaguti: "O direito penal, nessa linha, vai parecer como um discurso de classe que pretende legitimar a hegemonia do capital" 88 .

O fato de o agente estar desempregado influenciar na aplicação subjetiva de um tipo penal como o tráfico de drogas, remete-nos à época em que se criminalizava a vadiagem como desculpa para manter a parte da sociedade menos favorecida sob o controle do Estado. A partir desse ponto de vista, achamos que evoluímos quando esse tipo de conduta deixa de ser crime, mas na verdade só muda de roupagem e de contexto.

Segundo Zaccone ${ }^{89}$, o crime e a miséria têm sido constantemente associados. Parte da população e setores ditos progressistas tem tratado a pobreza como a causa da criminalidade, quando na realidade o que acontece é justamente um processo de criminalização da pobreza constante e perpétuo, que se alimenta através de discursos preconceituosos e estigmatizados. $\mathrm{O}$ autor define como o estereótipo do bandido:

$\mathrm{Na}$ figura de um jovem negro, funkeiro, morador da favela, próximo do tráfico de drogas vestido com tênis, boné, cordões, portador de algum sinal de orgulho ou de poder e de nenhum sinal de resignação ao desolador cenário de miséria e fome que o circunda. ${ }^{90}$

Portanto, quando o parágrafo segundo preconiza que o juiz atenderá às circunstâncias pessoais e sociais do agente, para decidir qual será o delito que corresponde melhor aos critérios previstos, estamos diante de um instrumento poderoso que seleciona quais corpos sofrerão as sanções penais. Não é novidade que esses corpos pertencem à população pobre e periférica.

O uso das circunstâncias sociais e pessoais é somente mais uma forma de legitimar a guerra aos pobres, criminalizando a população de classes mais baixas. De acordo com Baratta:

\footnotetext{
88 BATISTA, Vera Malaguti. Introdução crítica à criminologia brasileira. Rio de Janeiro: Revan, 2011, p. 80.

89 ZACCONE, Orlando. Acionistas do nada: quem são os traficantes de drogas. Rio de Janeiro: Revan, v. 2, 2007, p. 19.

${ }^{90}$ ZACCONE, Orlando. Acionistas do nada: quem são os traficantes de drogas. Rio de Janeiro: Revan, v. 2, 2007, p. 21.
} 
A inexistência de ações estrangeiras, de uma guerra contra as drogas conduzida em seu território, e a inexistência de uma guerra contra as drogas conduzidas pelo Brasil no território de outras nações faz com que, no Brasil, o problema da droga, simplesmente, assuma a forma da relação entre duas nações em que está dividida a sociedade brasileira: os ricos e os pobres. Assim, aos jovens consumidores das classes média e alta se aplica o paradigma médico ${ }^{91}$, enquanto que aos jovens moradores de favelas e bairros pobres se aplica o paradigma criminal. ${ }^{92}$

De um modo geral, para entendermos o tamanho do abismo social em que estamos inseridos, precisamos analisar esses aspectos como um todo. A natureza, a quantidade, o local, as circunstâncias pessoais e sociais somadas ao histórico do agente, transforma-se em uma máquina de reprodução de estereótipo, que nem o mais progressista ou garantista dos julgadores consegue se livrar. $\mathrm{Na}$ medida em que os estereótipos servem como um parâmetro, a criminalização dessa população acaba por perpetuar esses estereótipos. Então, um ciclo vicioso se forma.

O parágrafo segundo do artigo 28 previu um conjunto de palavras e critérios objetivos que estão positivados na Lei por um propósito bem demarcado e pensado. Aproveitar-se da estigmatização de uma parte determinada da sociedade para exercer a seletividade penal faz parte de uma motivação política nítida. Nesse sentido, Zaccone se apropria das palavras de Zaffaroni e afirma que:

A seletividade punitiva não é de toda arbitrária e se orienta pelos padrões de vulnerabilidade dos candidatos à criminalização, que, nesse caso, são as empresas mais débeis, presas fáceis da extorsão e, na cidade do Rio de Janeiro, são representadas pelo tríduo PRETO-POBRE-FAVELA. ${ }^{93}$

Por último, é preciso entendermos que quando o legislador resolve abordar os antecedentes criminais como critério de aplicação subjetiva, se pretendia perpetuar a qualidade de criminoso do agente. O critério de verificação de maus antecedentes já é questionável quando utilizado para somar a pena, como por exemplo ocorre com o artigo 59 do Código Penal.

\footnotetext{
${ }^{91} \mathrm{O}$ que nos remete ao modelo sanitário analisado anteriormente, em que o controle da população era feito através do argumento médico de internação compulsória.

${ }^{92}$ BARATTA, Alessandro. Prefácio. In: BATISTA, Vera Malaguti. Difíceis ganhos fáceis: drogas e juventude pobre no Rio de Janeiro. Instituto Carioca de Criminologia, 2003, p. 25.

93 ZACCONE, Orlando. Acionistas do nada: quem são os traficantes de drogas. Rio de Janeiro: Revan, v. 2, 2007, p. 24.
} 
Isso porquê, acaba tornando fatos anteriores, influentes nas penas dos fatos novos.

O problema é que nesse caso, os antecedentes estão sendo usados para determinar qual é o tipo pelo qual o agente será acusado e condenado. Significa dizer que se um indivíduo já foi condenado pela conduta de traficar drogas, ele provavelmente, sempre será visto como traficante, mesmo que estivesse somente utilizando a droga para consumo pessoal. Quando lemos essa parte do parágrafo $2^{\circ}$ pela primeira vez, o critério dos antecedentes parece inofensivo, mas quando o analisamos de perto, entendemos que é mais uma ferramenta de perpetuação da figura do traficante, ou seja, a condenação pelo tráfico passa a ser uma pena perpétua, modalidade inadmitida pelo ordenamento jurídico brasileiro.

Com o exposto, comprovou-se como a construção de um estereótipo desempenha influência na criminalização de certos grupos já determinados, exercendo a seletividade penal. De acordo com Zaffaroni: “estes estereótipos permitem a catalogação dos criminosos que combinam com a imagem que corresponde à descrição fabricada, deixando de fora outros tipos de delinquentes $^{94}$.

O estereótipo e o etiquetamento social foram, primeiramente, tratados pela teoria do labeling approach, que como já visto, significou uma mudança no olhar da criminologia determinista tradicional. O que está em jogo passa a ser quem tem o poder de definir e quem sofre a definição. Segundo essa teoria, a "criminalidade" se torna uma etiqueta atribuída a determinados indivíduos que as agências formais e informais entendem como criminosos e delinquentes. Nesse sentido, Howard Becker:

Não quero dizer com isto o que se compreende normalmente, ou seja, que as causas do desvio estão localizadas na situação social do desviante ou nos "fatores sociais" que induzem a ação. Quero dizer mais do que isso, que os grupos sociais criam o desvio ao fazer as regras cuja infração constitui desvio e ao aplicar essas regras à pessoas particulares e rotulá-las como marginais e desviantes. Deste ponto de vista,

${ }^{94}$ ZAFFARONI, Eugenio Raúl. Em busca das penas perdidas: a perda de legitimidade do sistema penal. Rio de Janeiro: Revan, 1991. p. 130. 
o desvio não é uma qualidade do ato que a pessoa comete, mas uma consequência da aplicação por outras pessoas de regras e sanções a um "transgressor". O desviante é alguém a quem aquele rótulo foi aplicado com sucesso; comportamento desviante é o comportamento que as pessoas rotulam como tal. ${ }^{95}$

O Status de delinquente seria produzido pelos efeitos estigmatizantes do sistema penal. O criminoso deixa de ser o ponto de partida e vira o objeto de análise de uma realidade que foi socialmente construída. Essa quebra com o paradigma etiológico é muito importante para o surgimento da criminologia crítica, mas o grande problema da teoria interacionista, é que não há uma pesquisa ampla sobre as condições que dão às regras gerais, a atribuição da qualidade criminal. De acordo com a crítica de Baratta:

$\mathrm{Na}$ teoria do labeling o privilegiamento das relações de hegemonia desloca a análise para um terreno abstrato, em que o momento político é definido de modo independente da estrutura econônmica das relações de produção e distribuição. Daí, resulta numa teoria em condições de descrever mecanismos de criminalização e de estigmatização, de referir estes mecanismos de poder de definição e à esfera política em que ele se insere, sem poder explicar, independente do exercício desde poder, a realidade social e o significado do desvio, de comportamentos socialmente negativos e da criminalização. ${ }^{96}$

Com a necessidade de introduzir um contexto econômico na explicação de todos esses processos de criminalização, surge a criminologia crítica. A ideia é absorver os conceitos produzidos pela teoria do labeling approach e ao mesmo tempo voltar o olhar para o viés econômico com o interesse de trazer os discursos abstratos para a realidade, na medida em que supre a falta de uma pesquisa mais aprofundada. Quando Vera Malaguti, analisa a obra de Baratta, descreve que:

Para ele, ela (a teoria do labeling approach) não questiona o poder de rotular que aparece quase como acidental. O labeling apresenta a sociedade numa perspectiva atomista, um conjunto caótico de pequenos grupos sem uma perspectiva macrossociológica. A visão a-histórica acaba produzindo um "teatro de aparências", onde nem as condições materiais nem a luta de classes têm visibilidade. Para ele, essa despolitização não foi capaz de aprofundar sua interpretação da questão criminal, nem de entender os mecanismos reguladores da população criminosa, nem as relações de poder sobre as classes criminalizadas.

\footnotetext{
95 BECKER, Howard. Uma teoria da ação coletiva. Rio de Janeiro: Zahar Editores, 1977, p.60.

96 BARATTA, Alessandro. Criminologia Crítica e Crítica do Direito Penal: introdução à sociologia do direito penal. Coleção Pensamento criminológico. Rio de Janeiro: Editora Revan $6^{\mathrm{a}}$ Edição, 2011, p.115.
} 
Seu caráter formalista e universalista acabou produzindo uma visão política de médio alcance, descolada da economia, do processo de acumulação do capital. ${ }^{97}$

É por essa falta que uma abordagem político-econômica faz, que passamos a analisar no último capítulo, qual é a principal função por trás da criminalização das drogas. Qual é o discurso que se legitima e que é comprado por toda a sociedade. Quais são as contradições e quais são as consequências dessa criminalização.

${ }^{97}$ BATISTA, Vera Malaguti. Introdução crítica à criminologia brasileira. Rio de Janeiro: Revan, 2011, p. 77. 


\section{Capítulo 04 - A principal função da criminalização das drogas}

\section{1 - O mito da proteção de um bem jurídico}

É bem verdade que quando adotamos a teoria do delito analítica tripartida como o norte do nosso direito penal, internalizamos que para haver um crime, seria necessário analisarmos por etapas, se a conduta praticada era típica, antijurídica e culpável. A ideia de proteção de um bem jurídico, encontra-se no primeiro critério a ser analisado: a tipicidade. Para tipificar uma conduta, precisamos enxergar uma lesividade a um bem jurídico, como por exemplo é o crime de homicídio em relação ao bem jurídico vida e o crime de estupro ao bem jurídico dignidade sexual. No caso da tipificação do uso e do tráfico de drogas, o bem jurídico a ser protegido seria a saúde pública.

Desde que os indivíduos se conhecem como tal, fazem uso de drogas. Há estudos que evidenciam o cultivo de drogas como o tabaco, a maconha e o álcool, nos anos mais remotos da civilização ${ }^{98}$. Então, por que tanto tempo depois, ainda persistimos em uma "guerra contra as drogas"?

Como abordado nos capítulos anteriores, aqui no Brasil, quem estabelece o que é droga ilícita ou não, é a ANVISA. Dentre as drogas que estão ainda criminalizadas, está a maconha, a cocaína, o crack, a heroína, etc. Muito curioso é o fato de o álcool não estar nesse rol, já que o argumento da criminalização é a proteção da saúde pública.

A Fundação Oswaldo Cruz (Fiocruz) realizou recentemente o Levantamento Nacional Sobre o Uso de Drogas pela População Brasileira, que se mostrou muito esclarecedor. No capítulo 08 desse levantamento,

\footnotetext{
${ }^{98}$ COLAVITTI, Fernanda. As drogas através dos Séculos. Revista Galileu, 2015. Disponível em: http://revistagalileu.globo.com/Galileu/0,6993,ECT1120198-1706-2,00.html. Acessado em: 10/06/2019.
} 
abordou as consequências do uso do álcool e das demais drogas ilícitas em diversos momentos, sendo o primeiro em relação ao trânsito:

a consequência maisfrequentemente associada ao uso de álcool foi dirigir sob o efeito de álcool,sendo estimado que aproximadamente $\mathbf{7 , 5 \%}$ dos indivíduos maiores de 12anos, nos últimos 12 meses - o que corresponde a, aproximadamente, 11.5 milhões de indivíduos que dirigiram sob efeito do álcool nos 12 mesesanteriores à entrevista. De forma algo similar (guardadas as diferenças demagnitude), a consequência mais frequentemente associada ao uso desubstâncias ilícitas também foi dirigir, sendo estimado que aproximadamente0,7\% dos indivíduos maiores de 12 anos, nos últimos 12 meses - o quecorresponde a, aproximadamente, 1.060 indivíduos. Ou seja, o hiato em termosde abrangência populacional entre o ato de dirigir sob efeito do álcool e sobefeito das demais substâncias seria de uma ordem de magnitude (ou ainda,10x mais frequente com relação ao álcool, na comparação com as demaissubstâncias) ${ }^{99}$. (grifei)

De acordo com a análise, o número de pessoas que dirigem alcoolizadas é demasiadamente maior do que pessoas que dirigem sob efeito de outras drogas ilícitas. O mesmo é observado em casos de violência perpetrada: “(..) a forma mais frequente de violência reportada tanto sob o efeito de álcool quanto sob o efeito de drogas foi ter discutido com alguém (2,9\% e 0,4\% para álcool e drogas, respetivamente)" ${ }^{\prime 100}$.

Nesse sentido, argumenta Zaccone em "Acionistas do Nada":

A incongruência entre a operacionalidade do sistema penal ("ser") e sua programação ("dever ser") também reside no fato de as drogas lícitas causarem resultados lesivos em número reconhecidamente maiores do que as drogas ilícitas. "O álcool e o fumo, que são drogas ilícitas, causam mais danos à saúde pública do que as ilícitas como maconha e cocaína", alerta a Organização Mundial da Saúde ${ }^{101}$.

De acordo com o relatório citado:

Entre os dez fatores de risco de se adquirir doenças evitáveis, o tabaco figura em quarto lugar, seguido pelo álcool, em quinto. Cigarros e bebidas alcoólicas contribuíram com $4,1 \%$ e $4 \%$, respectivamente, para as causas de doença em 2000 , enquanto substâncias ilícitas foram associadas a $0,8 \%$.

\footnotetext{
${ }^{99}$ FIOCRUZ, III Levantamento Nacional Sobre o Uso de Drogas pela População Brasileira, 2017, p.153.

Disponível em:https://www.documentcloud.org/documents/6111419.html?fbclid=IwAR3SBvjm9oJi8U1nQzc yJPLeXRSccq-zMBsCKgco1OBg-TP9XhdnlIqG8D8\#document/p1. Acessado em: 10/06/2019. ${ }^{100}$ FIOCRUZ, III Levantamento Nacional Sobre o Uso de Drogas pela População Brasileira, 2017, p.158.

Disponível em:https://www.documentcloud.org/documents/6111419.html?fbclid=IwAR3SBvjm9oJi8U1nQzc yJPLeXRSccq-zMBsCKgco1OBg-TP9XhdnlIqG8D8\#document/p1. Acessado em: 10/06/2019. ${ }^{101}$ ZACCONE, Orlando. Acionistas do nada: quem são os traficantes de drogas. Rio de Janeiro: Revan, v. 2, 2007, p. 38.
} 
Considerando ambos os relatos, o álcool como droga, seria mais perigoso à saúde pública do que as demais drogas ilícitas, bem como o tabaco que gera uma dependência significativa nos usuários pela substância da nicotina e, ainda assim, ambos não se encontram no rol da ANVISA. Uma vez comprovado que as mencionadas drogas são capazes de gerar um malefício à saúde pública maior do que as criminalizadas, em específico o álcool que é a causa, inclusive, de aumento de pena, qual seria o argumento então para mantê-las fora da lista das substâncias ilícitas? Ou seria melhor nos perguntarmos qual é o motivo por trás da manutenção das demais drogas como ilícitas e criminalizadas?

A criminalização não desmotiva os indivíduos a deixarem de consumir e usar a droga e, como consequência, o Estado deixa de ter o controle da qualidade do que a população está consumindo. Se a preocupação fosse realmente resguardar a saúde pública, o melhor caminho seria descriminalizar e regulamentar o uso dessas substâncias de modo a criar políticas públicas eficientes e eficazes.

Ademais, a preocupação com a saúde pública se consolida como um mito na medida em que o Estado legitima todos os dias uma guerra contra a própria população. A chamada "guerra às drogas" ofende mais à saúde pública do que a própria circulação dessas substâncias. Nesse sentido, Maria Lucia Karam assinala que:

Talvez seja, neste tema das drogas, onde mais fortemente se manifeste a enganosa publicidade do sistema penal, apresentando como instrumento capaz de solucionar conflitos, como o instrumento capaz de fornecer segurança e tranquilidade, através da punição dos autores de condutas que a lei define como crimes. Destinada a erradicar do globo todo um leque de compostos psicoativos, as diretrizes proibicionistas terminaram por produzir um efeito contrário: organizações ilegais fortaleceram-se, uma variedade maior de drogas ilícitas ficou à disposição dos interessados, e a violência que acompanha todo o negócio ilegal não cessou de crescer. Essas observações procedem e, diante delas, até mesmo um leitor francamente contrário ao uso de qualquer substância psicoativa estaria em condições de questionar o proibicionismo aplicado até hoje ${ }^{102}$.

102 KARAM, Maria Lucia. apud ZACCONE, Orlando. Acionistas do nada: quem são os traficantes de drogas. Rio de Janeiro: Revan, v. 2, 2007. 
Depois de analisar as consequências dessa criminalização e a falta de argumentos coerentes que expliquem a criminalização de algumas drogas, mas de outras não, conseguimos concluir que a intenção por trás dessa política criminal com derramamento de sangue, não se relaciona nem por um momento com a proteção de um bem jurídico.

Mas se ao criminalizar as drogas e as condutas afins, não resulta em um zelo pela saúde pública da população, então qual seria a principal função da criminalização dessas substâncias?

\section{2 - A principal função da criminalização das drogas}

Como visto no capítulo anterior, a criminalização das drogas no Brasil ocorreu nos moldes sanitários, em um primeiro momento e nos moldes bélicos logo após, como narrou Nilo Batista. O discurso médico foi utilizado para controlar os usuários de drogas, que acabaram por ser internados compulsoriamente, com o evoluir das legislações. Mas esse processo somente faz sentido se considerarmos os contextos políticos e econômicos da época. Existiu então um discurso moral capaz de criminalizar condutas que, a princípio, eram consideradas nocivas à sociedade, mas que no fundo, pretendia legitimar o controle da população.

É interessante pensar que esses discursos morais não foram utilizados somente no Brasil. Diversos autores quando tratam do histórico da criminalização das drogas pelo mundo, abordam como essa criminalização teve uma função determinada: o controle da população.

Não é possível entender o problema das drogas no Brasil, sem relacionar esse problema ao contexto econômico e político em que estamos inseridos. Caso contrário, estaríamos analisando somente conjunturas abstratas. Orlando Zaccone, ao narrar como ocorreu a criminalização das drogas, citando Rosal del Olmo, afirma que 
As reais funções sociais desenvolvidas pelas recentes políticas criminais no trato das substâncias psicoativas só poderão ser desvendadas através de uma análise crítica e histórica, afastando os estereótipos médico, moral e criminoso que, na lição da professora Rosa del Olmo "só contribui para reforçar a confusão reinante e para ignorar suas reais dimensões psicológicas e sociais, assim como políticas e econômicas" 103 .

Então, analisaremos alguns exemplos que mostram a importância do cenário político e econômico que ensejou a criminalização dessas substâncias. O primeiro episódio que podemos citar é em relação ao Ópio. Com o fomento da produção do ópio na Índia e a exportação para a China, onde houve um vasto número de adeptos à substância, os Ingleses auferiram grande lucro. Quando o Imperador da China Lin Tso-Siu decidiu apreender o carregamento com toneladas de ópio, trazidos pela companhia East India Company, resultou na declaração de guerra entre a China e a Inglaterra, com a vitória desta. As guerras que ocorreram nos anos 1839 e 1856, vislumbravam uma imensa lucratividade com o comércio legal do ópio, através da política do livre comércio ${ }^{104}$.

Devido ao início da revolução industrial, que demandava uma mão de obra extremamente produtiva, a qual necessitava trabalhar por mais de 12 horas ao dia para satisfazer os anseios do capital, as substâncias entorpecentes como o ópio e seus derivados, começaram a ser considerados um empecilho à produtividade. Assim, a Liga da Nações Unidas convocou uma reunião para tratar sobre a conferência de Xangai que se propunha analisar a questão do Ópio.

Os Estados Unidos, almejando frear o desenvolvimento inglês, convocaram a Convenção de Haia em 1912, com o fim de ratificar a Convenção de Xangai e proibir o comércio do Ópio. Os ingleses, por sua vez, condicionaram sua participação na Conferência de Haia à inclusão de outras substâncias, como a cocaína, de modo que outros países também sofressem

\footnotetext{
${ }^{103}$ DEL OLMO, Rosa apud ZACCONE, Orlando. Acionistas do nada: quem são os traficantes de drogas. Rio de Janeiro: Revan, v. 2, 2007, p. 78.

104 ZACCONE, Orlando. Acionistas do nada: quem são os traficantes de drogas. Rio de Janeiro: Revan, v. 2, 2007, p. 77.
} 
com a proibição, o que foi o caso da Alemanha, Holanda e França. Deu-se início ao controle internacional das drogas.

Esse é um dos exemplos em que observamos com clareza os objetivos políticos e econômicos por trás da proibição das drogas. A partir da necessidade do desenvolvimento industrial desenfreado, que ainda dependia dos indivíduos nas fábricas, o uso do ópio começou a ser proibido. Mas há outros exemplos que demonstram que a proibição, além de guardar um objetivo econômico e político, é "temperada e mascarada pelo conservadorismo da moralidade e dos bons costumes"105.

Os EUA são o exemplo perfeito de como a proibição da droga esconde mil e uma faces. Desde o fim de sua guerra civil, grupos se juntaram em torno de um discurso religioso e moral, clamando por ações do governo que fossem capazes de proibir o comércio, a produção e o uso de substâncias entorpecentes. A partir dessas campanhas, grupos foram diretamente relacionados às drogas, como prega Thiago Rodrigues:

Os chineses, vindos em larga escala para trabalhar na construção das estradas de ferro do oeste dos EUA, trouxeram o hábito de fumar ópio e a esse psicoativo foram ferrenhamente associados. A maconha era considerada, em princípios do século $\mathrm{XX}$, droga de mexicanos, grupo visto pelos brancos estadunidenses como indolentes, preguiçosos e, por vezes, agressivos. Aos negros, parcela da população lançada em miseráveis condições de vida, atribuía-se o uso de cocaína, prática que supostamente os tornava sexualmente agressivos. Por fim, o álcool era percebido como uma droga que era abusada pela comunidade de imigrantes irlandeses. Nos quatro casos, a mesma lógica: minorias e imigrantes portavam comportamentos moralmente reprováveis que ameaçavam valores profundos dos EUA. Segundo Passetti (1991), Escohoado (1998) e McAllister (2000), essas comunidades eram tidas pelo cidadão norte-americano, branco, de origem saxônica como entidades exógenas, estranhas e de hábitos perigosos, que traziam venenos e disputavam empregos com aqueles estabelecidos na América há gerações. ${ }^{106}$

Esse recorte nos traz uma lucidez quanto ao verdadeiro objetivo dos EUA: afastar e neutralizar as populações que são indesejáveis, exercendo um controle sobre elas. Esse discurso moral e protecionista ainda se mantém

\footnotetext{
105 ZACCONE, Orlando. Acionistas do nada: quem são os traficantes de drogas. Rio de Janeiro: Revan, v. 2, 2007, p. 81.

${ }^{106}$ RODRIGUES, Thiago. Narcotráfico:uma guerra na guerra. São Paulo: Desativo, 2003, p.83.
} 
como uma importante ferramenta de manipulação e criminalização das classes mais baixas e vulneráveis. Inclusive, foi através do discurso da Lei e Ordem $^{107}$, a qual serviu de instrumento indispensável de legitimação do sistema de justiça criminal, que o "mito da droga" aumentou a ilusão de segurança como argumento vendido pelos governos até hoje.

Entrando em uma conjuntura mais íntima, vemos que é exatamente isso o que ocorre no Brasil, mais especificamente no Rio de Janeiro. Cria-se uma política do medo, criam-se substâncias que precisam ser combatidas e cria-se também o inimigo da população a partir dos estereótipos traçados. Essas manifestações impulsionam o discurso criminalizante e o controle social. Consoante Zaccone:

No Brasil, a "guerra às drogas" é o carro-chefe da criminalização da pobreza, através dos discursos de lei e ordem disseminados pelo pânico. Bala perdida, roubo de veículos, queima de ônibus e até o comércio de produtos por camelôs são diferentes práticas ilícitas imputadas aos traficantes, que passam a construir "uma categoria fantasmática, uma categoria policial que migrou para a academia, para o jornalismo, para a psicologia e que não tem cara, não é mais humana. É uma coisa do mal" 108 .

A guerra às drogas, na verdade, é uma guerra aos pobres. O discurso que ouvimos na televisão, nas rádios e em todos os lugares, criando o medo na sociedade, têm a função de criminalizar um estrato da sociedade. A ordem pública cria inimigos para ter justificativa quando for abatê-los. Tudo é projetado e esquematizado. Vera Malaguti aduz que:

Os novos inimigos da ordem pública (ontem terroristas, hoje traficantes) são submetidos diuturnamente ao espetáculo penal, às visões de terror dos motins penitenciários e dos corredores da morte. Não é coincidência que a política criminal de drogas hegemônica no planeta se dirija aos pobres globais indiscriminadamente: sejam eles jovens favelados do Rio, camponeses da Colômbia ou imigrantes indesejáveis no hemisfério norte. ${ }^{109}$

A função da criminalização das drogas consiste em, através de um discurso manipulador, nutrido por estereótipos e alimentados pelas massas

\footnotetext{
${ }^{107}$ Lei de Ordem foi a política criminal vigente nos Estados Unidos, em especial a partir dos anos 1980

${ }^{108}$ ZACCONE, Orlando. Acionistas do nada: quem são os traficantes de drogas. Rio de Janeiro: Revan, v. 2, 2007, p. 115.

${ }^{109}$ BATISTA, Vera. Apud ZACCONE, Orlando. Acionistas do nada: quem são os traficantes de drogas. Rio de Janeiro: Revan, v. 2, 2007, p. 117.
} 
midiáticas, exercer um controle sobre determinada parte da sociedade que oferece perigo à classe dominante. A partir desses discursos, se legitima a violência contra essas pessoas, se legitima os estigmas, se legitima o encarceramento em massa e os processos de desumanização. A partir da lógica de um controle punitivo, que é uma das faces do controle social, uma seletividade penal é constituída, ou seja, somente quem precisa ser neutralizado, será penalizado.

Essa parte da sociedade que é alvo do controle punitivo do Estado e, por conseguinte, da seletividade penal, é a parte inserida nas classes econômicas mais baixas. Não é à toa que a guerra às drogas é conhecida também como a guerra aos pobres. Também não foi por acaso que essa parte da sociedade foi "escolhida" para figurar nesse polo. Consoante Alessandro Baratta:

Criminalizar os pobres é um instrumento indispensável porque garante materialmente a sua posição subalterna no mercado de trabalho e a sua crescente exclusão, disciplinando-os, pondo-os em guetos, e destruindo-os. É também indispensável para encobrir o grande edifício de ilegalidade e de violência que reúne em nossa sociedade as classes detentoras do poder econômico ${ }^{110}$.

Baratta mostra que o processo de criminalização é pensado como um processo classista, de modo que o poder punitivo estaria diretamente ligado ao controle e o disciplinamento para o mercado de trabalho. A constituição dos pobres como criminosos serve como um instrumento para a garantia da hegemonia do capital. Portanto, não teria como fugir da dialética do opressor e do oprimido. O discurso punitivo e a questão criminal não seriam nada além do que um discurso do capitalismo. Assim entendeu Evgeny Pashukanis, quando aborda que as leis penais são a falsa consciência e fetichismo do capitalismo $^{111}$.

Vera Malaguti pontua que embora as demandas da política criminal tivessem roupagens diferentes ao longo das experiências sociais e históricas,

\footnotetext{
${ }^{110}$ BARATTA, Alessandro. Prefácio. In: BATISTA, Vera Malaguti. Difíceis ganhos fáceis: drogas e juventude pobre no Rio de Janeiro. Instituto Carioca de Criminologia, 2003, p. 31.

${ }^{111}$ BATISTA, Vera Malaguti. Introdução crítica à criminologia brasileira. Rio de Janeiro: Revan, 2011, p.85.
} 
no final das contas, há sempre uma atualização dessas demandas, independentemente da circunstância:

Existem então demandas distintas de política criminal. O absolutismo gerava demandas de ordem a partir do capital mercantil, a burguesia ascendente demandava garantias para a exploração intensiva da mão de obra para a revolução industrial e daí por diante, até as demandas atuais do capitalismo videofinanceiro. Aprendemos com Zaffaroni que, nas margens do capitalismo central, na nossa periferia, ocorre uma "transculturação" das políticas criminais que se atualizam sucessivamente diante das revoluções: a mercantil, a industrial e a tecnocientífica ${ }^{112}$.

Preenche-se o vazio que permeava a teoria do labeling approach. Aqui, a questão político-econômica é abordada, na medida em que se pensa o processo de criminalização inteiramente ligado ao poder econômico e à relação de trabalho. O sistema de justiça criminal da sociedade capitalista serve para disciplinar despossuídos para constrangê-los a aceitar a moral do trabalho que lhes é imposta pela posição subalterna na divisão do trabalho ${ }^{113}$.

Embora a teoria liberal do labeling approach tenha construído uma importantíssima quebra do paradigma etiológico, introduzindo a sistemática do etiquetamento social e trazendo a importância dos criminosos como figuras construídas por estereótipos, ainda havia uma falha, pois era necessário investigar o foco desses discursos criminalizantes. A partir dessa lacuna, a criminologia crítica utiliza uma base marxista para entender a questão criminal. O poder punitivo não é mais pensado em abstrato, ele tem ligação direta com o sistema de produção. Para Baratta "existiria um nexo funcional entre os mecanismos seletivos e o processo de acumulação de capital. Quem não entender a luta de classes por trás dos processos de criminalização, não dará conta do problema"114.

Seguindo este entendimento, a criminalização das drogas insere-se como um instrumento eficaz e efetivo da seletividade penal. O estigma

\footnotetext{
${ }^{112}$ BATISTA, Vera Malaguti. Introdução crítica à criminologia brasileira. Rio de Janeiro: Revan, 2011, p.80.

113 BATISTA, Vera Malaguti. Difíceis ganhos fáceis: drogas e juventude pobre no Rio de Janeiro. Instituto Carioca de Criminologia, 2003, p.15.

${ }^{114}$ BATISTA, Vera Malaguti. Introdução crítica à criminologia brasileira. Rio de Janeiro: Revan, 2011, p. 90.
} 
construído na figura do traficante, que por sua vez, pertence à classe mais pobre da sociedade, e a vigência de uma lei que permite a aplicação subjetiva por parte do magistrado, dos artigos que determinam a conduta de tráfico ou de consumo pessoal de droga, fez com que a criação da guerra às drogas nas favelas e nas comunidades do Rio de Janeiro, como forma de manutenção da hegemonia do capitalismo, caísse como uma luva para a classe dominante. Assim, trata Zaccone:

Prender, processar e julgar os indivíduos que realizarem as condutas descritas na lei como tráfico de drogas é tão somente uma parcela do controle social na questão envolvendo estas substâncias proibidas. O controle sobre as populações pobres e, principalmente, na cidade do Rio de Janeiro, das áreas ocupadas por essa população conhecidas por "favelas", é o exemplo mais gritante do exercício do poder configurador positivo ${ }^{115}$.

Com isso, concluímos que a principal função da criminalização das drogas, é legitimar a seletividade penal através do controle dessa população. O resultado dessa criminalização em massa é sentido pelos milhares de encarcerados nas cadeias do Rio de Janeiro.

\section{3 - Os reflexos da criminalização no cárcere}

O encarceramento é uma das mais antigas formas de punição. As primeiras prisões, conhecidas como rasphuis, concebidas em meados do século XVI, eram dispositivos de disciplinamento e correção da juventude. Já no século XVIII, com a revolução industrial que significou um moinho de gastar gente, o direito penal foi concebido para gerir as ilegalidades. Nesse sentido, John Howard escreveu um relatório ainda no século XVIII, que poderia ser considerado atual ainda nos dias de hoje: pobres amontoados em situações insalubres, sem luz e sem alimentação digna.

\footnotetext{
${ }^{115}$ ZACCONE, Orlando. Acionistas do nada: quem são os traficantes de drogas. Rio de Janeiro: Revan, v. 2, 2007, p.30.
} 
Do século XVII ao XIX, a prisão virou um instrumento disciplinar exaustivo, se tornando a pena principal do ocidente ${ }^{116}$. Já no século XX, com o neoliberalismo, "a prisão não perdeu sentido, tão somente conjugou o sistema penal com novas tecnologias de controle e vigilância, de constituição dos bairros pobres do mundo em campos de concentração"117.

O Século XXI também não apresentou grandes mudanças no modo de pensar o encarceramento em massa. No contexto nacional, como já mencionado, o Brasil com 726.712 de pessoas presas, é um dos países que mais encarcera no mundo, perdendo somente para os Estados Unidos e China $^{118}$ que mantém 2 milhões e 1 milhão e 600 mil pessoas presas, respectivamente. A prisão é também uma das agências de criminalização secundária, na medida em que perpetua a seletividade penal na sociedade.

No Brasil, as condenações por tráfico de drogas, vem exercendo grande influência nesse número que aumenta exponencialmente. A partir dos dados colhidos pelo DEPEN de junho de $2016^{119}$, o tráfico de drogas é o responsável por $26 \%$ dos crimes cometidos no Brasil, se igualando ao crime de roubo. Isso significa dizer que há 176.691 pessoas presas em decorrência da lei de drogas, atualmente. Somente no Estado do Rio de Janeiro, em junho de 2016, tinham 50.219 pessoas cumprindo pena, ficando somente atrás de São Paulo, Minas Gerais e Paraná.

Os dados recolhidos pelo DEPEN, procuram traçar o perfil do indivíduo encarcerado. Dos aspectos que são analisados, para esse trabalho

\footnotetext{
${ }^{116}$ BATISTA, Vera Malaguti. Introdução crítica à criminologia brasileira. Rio de Janeiro: Revan, 2011, p. 94-96.

${ }^{117}$ BATISTA, Vera Malaguti. Introdução crítica à criminologia brasileira. Rio de Janeiro: Revan, 2011, p. 99.

${ }^{118}$ BRASIL. Ministério da Justiça. Departamento Penitenciário Nacional. Levantamento Nacional de Informações Penitenciárias. Infopen, junho de 2016. Disponível em: https://www.conjur.com.br/dl/infopen-levantamento.pdf. Acesso em:12 de junho de 2019

${ }^{119}$ BRASIL. Ministério da Justiça. Departamento Penitenciário Nacional. Levantamento Nacional de Informações Penitenciárias. Infopen, junho de 2016. Disponível em: https://www.conjur.com.br/dl/infopen-levantamento.pdf. Acesso em:12 de junho de 2019.
} 
serão levados em consideração a faixa etária, a raça/cor, a escolaridade e o tipo penal.

Começando pela faixa etária, analisamos pelo gráfico 16, que $30 \%$ dos encarcerados têm entre 18 e 24 anos. Logo após, com 25\%, estão os encarcerados com 25 a 29 anos. Isso nos mostra que mais da metade da população encarcerada no Brasil, têm menos de 30 anos. Especificamente no Estado do Rio de Janeiro, esse número corresponde a $37 \%$ e $22 \%$, respectivamente ${ }^{120}$.

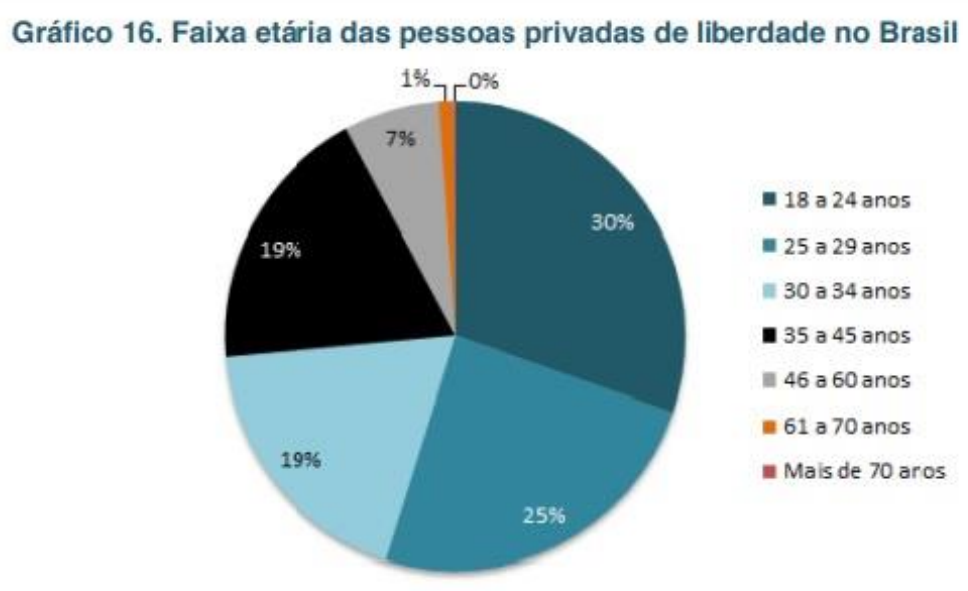

Fonte: Levantamento Nacional de Intormaçōes Penitenciárias - Infopen, Junho/2016

Em relação a raça/cor, constata-se, pela figura 04 , que $64 \%$ das pessoas que estão cumprimento pena no sistema prisional, são negras ou pardas e $35 \%$ são brancas. Esse número se mostra desafiador, tendo em vista que a maior parte da população do Brasil é considerada negra ou parda, representada pelo número de $53 \%$, em contraposição dos $46 \%$ considerados brancos. No Rio de Janeiro, os números apresentam uma disparidade de $70 \%$ e $22 \%$, respectivamente ${ }^{121}$.

\footnotetext{
${ }^{120}$ BRASIL. Ministério da Justiça. Departamento Penitenciário Nacional. Levantamento Nacional de Informações Penitenciárias. Infopen, junho de 2014. Disponível em: $<$ http://www.justica.gov.br/news/mj-divulgara-novo-relatorio-do-infopen-nesta-tercafeira/relatoriodepen-versao-web.pdf $>$. Acesso em:13/06/2019.

${ }^{121}$ BRASIL. Ministério da Justiça. Departamento Penitenciário Nacional. Levantamento Nacional de Informações Penitenciárias. Infopen, junho de 2014. Disponível em: $<$ http://www.justica.gov.br/news/mj-divulgara-novo-relatorio-do-infopen-nesta-tercafeira/relatoriodepen-versao-web.pdf $>$. Acesso em: 13/06/2019.
} 
Figura 4. Raça, cor ou etnia das pessoas privadas de liberdade e da população total

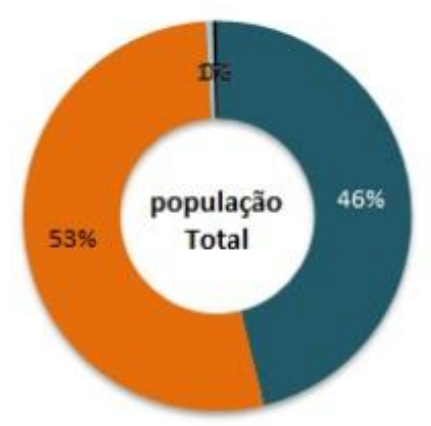

- Branca

megra

in Amare la

- indigena

In Outras

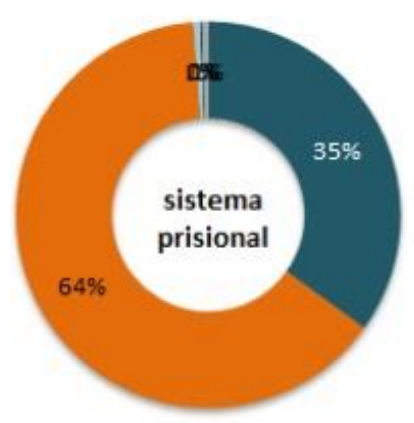

Fonte: Levantamento Nacional de Informaçōes Penitenciárias - Infopen, Junho/2016; PNAD, 2015.

Passamos à investigação acerca da escolaridade da população encarcerada. Analisando o gráfico 17, percebe-se que a maioria dos apenados, representando $51 \%$ do total, tem somente o ensino fundamental incompleto, seguido dos $14 \%$ com o ensino fundamental completo. No Rio de Janeiro, esses números correspondem também à maioria, com 65\% e 15\%, respectivamente ${ }^{122}$.

\section{Gráfico 17. Escolaridade das pessoas privadas de liberdade no Brasil}
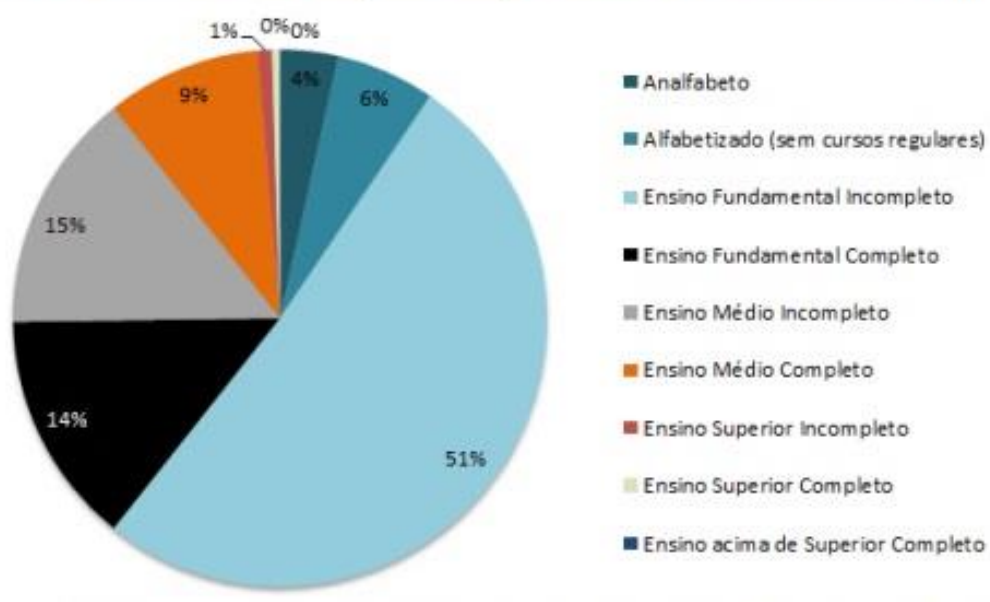

Fonte: Levantamento Nacional de Informações Penitenciárias - Infopen, Junho/2016.

Finalmente, quando investigamos a porcentagem demonstrada pela figura 06, que corresponde ao tipo do delito cometido, observamos que o

\footnotetext{
${ }^{122}$ BRASIL. Ministério da Justiça. Departamento Penitenciário Nacional. Levantamento Nacional de Informações Penitenciárias. Infopen, junho de 2014. Disponível em: <http://www.justica.gov.br/news/mj-divulgara-novo-relatorio-do-infopen-nesta-tercafeira/relatoriodepen-versao-web.pdf $>$. Acesso em: 13/06/2019.
} 
tráfico de drogas é o segundo maior responsável pelo aprisionamento no Brasil, tratando-se de $26 \%$ dos crimes, igualando-se ao roubo com também $26 \%$, quando se trata das cadeias masculinas. Em relação às Mulheres, o tráfico é a causa de $62 \%$ das prisões, enquanto o roubo, em segundo lugar, se apresenta somente como $11 \%$ dos crimes que ocasionaram prisão ${ }^{123}$.

Figura 6. Distribuição por gênero dos crimes tentados/consumados entre os registros das pessoas privadas de liberdade, por tipo penal
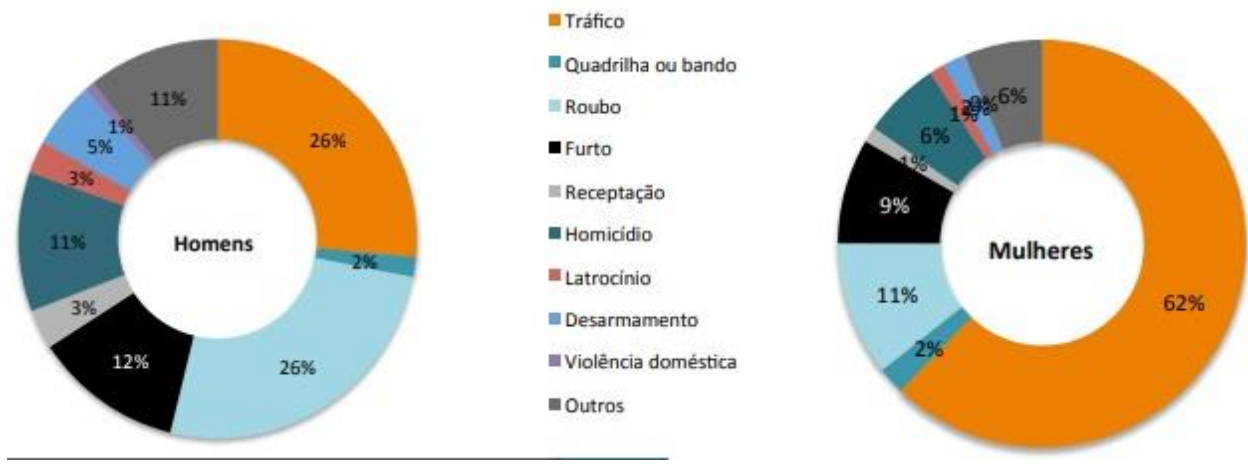

O que podemos concluir com esse panorama é que a cadeia recebe, majoritariamente, homens muito jovens, que não tiveram quase nenhuma escolaridade, negros e pardos e que estão presos por tráfico/roubo. Quando traçamos esse perfil, tudo nos leva a crer que a prisão está, efetivamente, servindo como um instrumento poderoso de seletividade penal.

Dos dados que mais chamam a atenção, o nível dos delitos de tráfico que culminaram em prisão no Estado do Rio de Janeiro, é assustador. Esses números somente retratam o que esse trabalho se propôs a analisar: A aplicação subjetiva do artigo de tráfico e de uso, a partir do estigma e da construção de um estereótipo da figura do traficante, exerce, sem nenhuma dúvida, uma seletividade penal. Com o contexto político e econômico que nos recai atualmente, a situação só tende a piorar.

\footnotetext{
${ }^{123}$ BRASIL. Ministério da Justiça. Departamento Penitenciário Nacional. Levantamento Nacional de Informações Penitenciárias. Infopen, junho de 2014. Disponível em: <http://www.justica.gov.br/news/mj-divulgara-novo-relatorio-do-infopen-nesta-tercafeira/relatoriodepen-versao-web.pdf>. Acesso em: 13/06/2019.
} 


\section{Conclusão:}

A seletividade na punição pelo crime de tráfico de drogas perpassa os processos de criminalização primário e secundário, como anteriormente analisados. A partir dessa compreensão, o presente trabalho buscou analisar de que forma, os referidos processos exercem essa seletividade.

Para este fim, foi utilizado o marco teórico da criminologia crítica, para no final do trabalho, apresentar qual é a principal função de criminalizar as drogas no Brasil. Esse marco é importante porque tirou a discussão sobre o controle social, a criação dos estereótipos, os processos de criminalização e a seletividade penal, de um plano abstrato, atribuindo ao aspecto político econômico uma importância estrutural.

O ponto de partida para a realização dessa investigação, foi escolher o cenário do Rio de Janeiro para materializar a discussão, de modo que pudéssemos sair do campo das ideias e demonstrar com exemplos reais, o impacto dessa criminalização em uma das cidades mais conhecidas do país. De início, concluímos que a cidade do Rio de Janeiro é alvo de "políticas públicas" desde o período da pós-escravidão, quando se realizou um plano urbano de exclusão da massa pobre. Verificamos que as consequências dessa exclusão podem ser vistas até hoje na cidade, que se tornou o cenário ideal para o que chamou de "guerra aos pobres".

Passamos a analisar, então, como ocorreu o processo de criminalização das drogas no Brasil, para chegarmos no objeto principal do trabalho: a seletividade penal na aplicação dos artigos 28 e 33 da Lei de Drogas. Ao final do capítulo, restou comprovado que a construção de estigmas e estereótipos pelas diversas agências de criminalização, exerce uma influência direta na decisão dos magistrados em atribuir a qualidade de traficante ou de usuário ao indivíduo. Verificamos a existência de aspectos 
subjetivos para a determinação desse "título", resultando na perpetuação dos estigmas e da construção da figura do traficante como um jovem negro, com baixa escolaridade, pobre e morador das favelas e subúrbios.

A discussão sobre a criminalização das drogas é ampla no cenário global e nacional. Está em pauta, atualmente, no Supremo Tribunal Federal, o julgamento que discute a possibilidade de descriminalizar o porte de drogas para consumo próprio, com o objeto centrado na maconha. Embora esse julgamento possa dar fruto a uma importante conquista e progresso no âmbito da discussão das drogas, não podemos ser hipócritas e ingênuos. A tipificação por tráfico de drogas não atinge a classe média/alta de uma forma geral, então tratar da descriminalização do porte para consumo pessoal, ainda que seja um avanço, não é capaz de acabar com o problema, porque só trará mais conforto para essas classes privilegiadas.

Por último, é necessário esclarecer que o objetivo desse trabalho não foi pregar um discurso punitivista em relação as classes abastadas, que não sofrem os mesmos processos de criminalização do que as classes dominadas. Pois como bem expresso Juarez Tavares, "não se pode resolver injustiça social com injustiça penal" ${ }^{24}$. Do contrário, estaríamos fazendo jus ao que Maria Lucia Karam chamou de "esquerda punitiva" 25.

O objetivo é tão somente mostrar como a criminalização das drogas exerce uma seletividade penal. Considerando todos os discursos deterministas, preconceituosos e morais, podemos concluir com tranquilidade que a criminalização das drogas e a idealização de uma guerra, não passa de uma máscara que pretende esconder a real intenção das agências criminalizadoras: neutralizar, desumanizar, segregar, trucidar e selecionar os pobres.

\footnotetext{
124 TAVARES, Juarez. Os limites dogmáticos da cooperação penal internacional. In: CERVINI, J. Princípios de Cooperação Judicial Penal Internacional no protocolo do Mercosul. Revista dos Tribunais, 2000, p. 174

${ }^{125}$ KARAM, Maria Lúcia. A esquerda punitiva. In: Discursos Sediciosos - Crime, Direito e Sociedade, $\mathrm{n}^{\circ} 1$. Rio de Janeiro: Relume-Dumará, 1996, p.79.
} 


\section{Referências bibliográficas:}

ANITUA, Gabriel. História dos pensamentos criminológicos. Rio de Janeiro, Editora Revan: 2008.

BARATTA, Alessandro. Criminologia Crítica e Crítica do Direito Penal: introdução à sociologia do direito penal. Coleção Pensamento criminológico. Rio de Janeiro: Editora Revan, 6a Edição, 2011.

BATISTA, Nilo et al. Direito Penal Brasileiro: primeiro volume: Teoria Geral do Direito Penal. Rio de Janeiro, RJ: Revan, 2003.

BATISTA, Nilo. Política criminal com derramamento de sangue. Discursos sediciosos, v. 3, n. 5-6, p. 77-94, 1998.

BATISTA, Vera Malaguti. Difíceis ganhos fáceis: drogas e juventude pobre no Rio de Janeiro. Instituto Carioca de Criminologia, 2003.

BATISTA, Vera Malaguti. Introdução crítica à criminologia brasileira. Rio de Janeiro: Revan, 2011.

BECCARIA, Cesare. Dos delitos e das penas. Trad. Lucia Guidicini e Alessandro Berti Contessa. 2005.

BOITEUX, Luciana. "Drogas e cárcere: repressão às drogas, aumento da população penitenciária brasileira e alternativas". In: SHECAIRA, Sérgio Salomão (Org.). Drogas: uma nova perspectiva São Paulo: IBCCRIM, 2014.

BRASIL. Código Penal de 1830. Disponível em: http://www.planalto.gov.br/ccivil_03/LEIS/LIM/LIM-16-12-1830.htm. Acesso em 31/05/2019.

BRASIL. Código Penal de 1890. Disponível em: http://www.planalto.gov.br/ccivil_03/decreto/1851-1899/D847.htm. Acesso em: 31/05/2019.

BRASIL. Constituição da República Federativa do Brasil de 1988. Disponível em: http://www.planalto.gov.br/ccivil_03/constituicao/constituicao.htm. Acessado em:10/06/2019

BRASIL. Decreto Lei $\mathrm{n}^{\circ} 3.689$ de 03 de outubro de 1941. Disponível em: http://www.planalto.gov.br/ccivil_03/decreto-lei/del3689.htm. Acessao em: $10 / 06 / 2019$

BRASIL. Decreto ${ }^{\circ}$ 11.841, de 10 de fevereiro de 1915. Disponível em: . Acesso em: 31/05/2019.

BRASIL. Decreto $\mathrm{n}^{\circ}$ 20.390, de 11 de Janeiro de 1932, Disponível em: http://www.planalto.gov.br/ccivil_03/decreto/1930-1949/D20931.htm. Acesso em: 31/05/2019.

BRASIL. Decreto-Lei No 2.848, De 7 De Dezembro De 1940. Disponível em: http://www.planalto.gov.br/ccivil_03/decreto-lei/del2848compilado.htm.

Acessado em:01/06/2019 
BRASIL. Lei $\mathrm{n}^{\mathrm{o}} 11.343$ de 23 de agosto de 2006. Disponível em: http://www.planalto.gov.br/ccivil_03/_ato2004-2006/2006/lei/111343.htm.

Acessado em: 01/06/2019.

BRASIL. Lei $\mathrm{n}^{\mathrm{o}} 5.276$ de 29 de outubro de 1971. Disponível em: https://www2.camara.leg.br/legin/fed/lei/1970-1979/lei-5726-29-outubro-1971358075- publicacaooriginal-1-pl.html. Acessado em: 01/06/2019.

BRASIL. Lei $\mathrm{n}^{\mathrm{o}} 6.368 / 76$ de 21 de outubro de 1976. Disponível em: http://www.planalto.gov.br/ccivil_03/LEIS/L6368.htm. Acessado em: 01/06/2019.

BRASIL. Lei $\mathrm{n}^{\mathrm{o}} 8.072$ de 25 de Julho de 1990. Disponível em: http://www.planalto.gov.br/ccivil_03/Leis/L8072.htm. Acessado em: 01/06/2019.

BRASIL. Lei $\mathrm{n}^{\circ} 9.099$ de 26 de setembro de 1995. Disponível em: http://www.planalto.gov.br/ccivil_03/leis/19099.htm. Acessado em: 01/06/2019.

BRASIL. Ministério da Justiça. Departamento Penitenciário Nacional. Levantamento Nacional de Informações Penitenciárias. Infopen, junho de 2016

BRASIL. Ordenações Filipinas, Título LXXXIX. Disponível em: https://www.diariodasleis.com.br/tabelas/ordenacoes/1-274-103-1451-04-0589.pdf. Acesso em: 31/05/2019.

DE CARVALHO, Salo. A política criminal de drogas no Brasil, Rio, ed. Luam, 1996.

DEL OLMO, Rosa. A América Latina e sua criminologia. Editora Revan, 2004.

FIOCRUZ, III Levantamento Nacional Sobre o Uso de Drogas pela População Brasileira, 2017.

GRELlET, F. Tiroteios no Rio migram da zona norte para a oeste. Brasil.estadão.com, 25 de fevereiro de 2018.

KARAM, Maria Lúcia. A esquerda punitiva. In: Discursos Sediciosos - Crime, Direito e Sociedade, nº1. Rio de Janeiro: Relume-Dumará, 1996, p.79.

KIRCHHEIMER, Otto; RUSCHE, Georg. Punição e estrutura social. Rio de Janeiro: Revan, 2004.

MOLINA, Antonio García-Pablos de \& GOMES, Luiz Flávio. Criminologia. 4. ed. São Paulo: Editora revista dos tribunias, 2002.

O GLOBO. Números da violência no Rio se assemelham aos de países em guerra. Globo.com (Jornal Nacional), 09 de maio de 2017.

O GLOBO. Rocinha: maior favela do país. Globo.com, 17 de setembro de 2018.

Observatório Legistativo da Intervenção Federal na Segurança Pública do Rio de Janeiro. Favelas cariocas.

PEDRINHA, Roberta Duboc. Notas sobre a política criminal de drogas no Brasil: Elementos para uma reflexão crítica. Fls. 5486. Disponível em:http://www.publicadireito.com.br/conpedi/manaus/arquivos/anais/salvador/rob erta_duboc_pedrinha.pdf 
PITOMBO, Cleunice A. Valentim Bastos. Da busca e da apreensão no processo penal. São Paulo: Editora Revista dos Tribunais, 1999.

RODRIGUES, Thiago. Narcotráfico:uma guerra na guerra. São Paulo: Desativo, 2003.

STF, Habeas-corpus no 111.840, Rel. Ministro Dias Toffoli, Brasília, DF, 2012.

STJ. Habeas-corpus nº 160.320. Rel. Ministra Laurita Vaz, Brasília, DF, 2011.

TAVARES, Juarez. Os limites dogmáticos da cooperação penal internacional. In: CERVINI, J. Princípios de Cooperação Judicial Penal Internacional no protocolo do Mercosul. Revista dos Tribunais, 2000.

ZACCONE, Orlando. Acionistas do nada: quem são os traficantes de drogas. Rio de Janeiro: Revan, v. 2, 2007.

ZAFFARONI, Eugenio Raúl. "La legislación anti-droga latinoamericana: Sus componentes de Derecho Penal Autoritario". Publicado em: Anuario No. 13-14 del Instituto de Ciencias Penales y Criminológicas de la Universidad Central de Venezuela, Caracas, 1995.

ZAFFARONI, Eugenio Raúl. Em busca das penas perdidas: a perda de legitimidade do sistema penal. Rio de Janeiro: Revan, 1991.

ZAFFARONI, Eugenio Raúl; PIERANGELI, José Henrique. Manual de direito penal brasileiro: Parte Geral, v. I. 7. ed. rev. atual. São Paulo: RT, 2007. 